\title{
T-DNA insertional mutagenesis in Arabidopsis: a tool for functional genomics
}

\author{
Resmi Nath Radhamony \\ National Research Centre on Plant Biotechnology \\ Indian Agricultural Research Institute \\ New Delhi, India \\ Tel: 911125841787223 \\ Fax: 911125843984 \\ E-mail: rnradhamony@ucdavis.edu \\ Anand Mohan Prasad \\ National Research Centre on Plant Biotechnology \\ Indian Agricultural Research Institute \\ New Delhi, India \\ Tel: 911125841787223 \\ Fax: 911125843984 \\ E-mail: prasad_anand@yahoo.com \\ Ramamurthy Srinivasan* \\ National Research Centre on Plant Biotechnology \\ Indian Agricultural Research Institute \\ New Delhi, India \\ Tel: 911125841787222 \\ Fax: 911125843984 \\ E-mail: sri@iari.res.in
}

Financial support: CGP project of NATP (CGP II/253) to RS and Senior Research Fellowships of CSIR to RNR and AMP.

Keywords: Arabidopsis, functional genomics, insertional mutagenesis, promoter trapping, T-DNA tagging.

${ }^{\#}$ Present address: Plant Biology, Division of Biological Sciences, University of California, Davis, CA, USA. Tel: 5307549852, Fax: 5307525410.

With the availability of complete genome sequences of several organisms, the focus has shifted from structural genomics to functional genomics, specifically in plants where the complete genomic sequences are becoming available i.e., Arabidoposis and rice. Agrobacterium mediated transformation which is exploited for transgenic technology is also being used as an effective mutagen and as a tool for functional genomics in higher plants. Besides the fact that the insertion of T-DNA element into a gene can lead to loss or gain of function, ingenious use of a variety of vectors have led to the identification of genes and regulatory elements in Arabidopsis. In this review, we highlight the progress made in the field of functional genomics of Arabidopsis using T-DNA tagging. Since this strategy has been very successfully employed in Arabidopsis and is now being extended to other plant species, we discuss the various vectors and experimental approaches employed to tag, identify and clone genes and promoter elements in Arabidopsis using T-DNA as a tool.
The completion of sequencing of the genome of Arabidopsis thaliana (AGI, 2000) marks a major milestone in plant biology research. The determination and analysis of the genome sequence of Arabidopsis have provided the first detailed description of the genetic blue print of a higher plant (Lin et al. 1999) and revealed several novel processes involved in plant growth and development. The availability of genome sequence of Arabidopsis is likely to broaden and accelerate further research in plant sciences. With the availability of complete genome sequences, the focus of research world wide is now on functional genomics and to assign functions to newly identified DNA sequences. Having identified a new sequence, the comparison with sequences in the databases is the simplest way to obtain functional information. Although efficient bioinformatics tools are becoming available for the annotation of genome sequences, in silico analysis by itselfis only indicative and is generally not sufficient to define function of a gene. Even in those cases where some indications become available from in silico analyses, experimental evidences are required. One of the most challenging tasks before plant

*Corresponding author 
Table 1. T-DNA insertion collections by various groups and their availability in stock centers ${ }^{1}$.

\begin{tabular}{|c|c|c|c|c|c|}
\hline $\begin{array}{l}\text { Submitted } \\
\text { by }\end{array}$ & Background & Selectable marker & $\begin{array}{c}\text { Promoter/enhancer/rep } \\
\text { orter gene }\end{array}$ & Population size & References \\
\hline SALK & Columbia-0 & Kanamycin & --- & 145589 & Alonso et al. 2003 \\
\hline GABI-Kat ${ }^{2}$ & Columbia-0 & Sulfadiazine & --- & 59455 & Rosso et al. 2003 \\
\hline Czaba Koncz & & Hygromycin & --- & 300 & Szabados et al. 2002 \\
\hline Syngenta & $\mathrm{C} 24$ & Hygromycin & GUS & 1250 & Sessions et al. 2002 \\
\hline $\begin{array}{l}\text { INRA- } \\
\text { Versailles }\end{array}$ & Ws, (Wassil-evskija) & Basta & GUS & 1480 & Balzergue et al. 2001 \\
\hline $\begin{array}{l}\text { Le Clere and } \\
\text { Bartel }\end{array}$ & Columbia & Basta & CaMV35S-cDNA & 33100 & $\begin{array}{l}\text { LeClere and Bartel, } \\
\qquad 2001\end{array}$ \\
\hline Haseloff & $\mathrm{C} 24$ & Kanamycin & GAL4-GFP & 8000 & Kiegle et al. 2000 \\
\hline Weigel & Columbia & Basta & $\begin{array}{l}\text { Multimerised } \\
\text { CaMV35S } \\
\text { enhancers }\end{array}$ & $>20000$ & Weigel et al. 2000 \\
\hline $\begin{array}{c}\text { Sussman and } \\
\text { Amasino }^{3}\end{array}$ & Ws-2 & Kanamycin & Ap2::GUS & 37800 & Sussman et al. 2000 \\
\hline Jack & Columbia & Kanamycin & CaMV-GUS & 11370 & Campisi et al. 1999 \\
\hline Ehrhardt & Col-2 (CS907) & Basta & CaMV 35S -GFP & 108 & Cutler et al. 2000 \\
\hline Feldmann & Ws & Kanamycin & --- & 4900 & $\begin{array}{l}\text { Azpiroz-Leehan and } \\
\text { Feldmann, } 1997\end{array}$ \\
\hline Gallois & $\mathrm{C} 24$ & Kanamycin & GUS & 283 & Devic et al. 1995 \\
\hline $\begin{array}{c}\text { Keith } \\
\text { Lindsey }^{4}\end{array}$ & $\begin{array}{l}\text { C24, Lands-berg } \\
\text { erecta }\end{array}$ & Kanamycin & GUS & 100 & Lindsey et al. 1993 \\
\hline $\begin{array}{c}\text { Bressan and } \\
\text { Yokoi }\end{array}$ & $\mathrm{C} 24$ & Basta & $\begin{array}{l}\text { Multimerised } \\
\text { CaMV35S } \\
\text { enhancers }\end{array}$ & 27330 & ABRC website \\
\hline $\begin{array}{l}\text { Scheible and } \\
\text { Somerville }\end{array}$ & Columbia & Basta & $\begin{array}{l}\text { Multimerised } \\
\text { CaMV35S } \\
\text { enhancers }\end{array}$ & $>145600$ & ABRC website \\
\hline
\end{tabular}

scientists is assigning functions to a large number of plant genes. The functions of $\sim 69 \%$ of the genes were classified according to sequence similarity to proteins of known function in all organisms (AGI, 2000). Definitive functions for individual genes have been thoroughly established for less than 10\% (Ostergaard and Yanofsky, 2004). Out of the
26000 genes identified in Arabidopsis, the functions of only a few thousand have been defined with great confidence (Bouche and Bouchez, 2001) and more than $30 \%$ of the predicted Arabidopsis genes could not be assigned any specific function (AGI, 2000). 
T-DNA insertional mutagenesis in Arabidopsis: a tool for functional genomics

Table 2. Gene disruption resources in Arabidopsis.

\begin{tabular}{|l|l|l|}
\hline \multicolumn{1}{|c|}{ Laboratory } & \multicolumn{1}{|c|}{ Sequenced insertions } & \multicolumn{1}{c|}{ Source } \\
\hline Salk Institute & 94947 & http://signal.salk.edu/cgi-bin/tdnaexpress \\
\hline TMRI & 100000 & http://www.tmri.org/en/partnership/sail_collection.aspx \\
\hline GABI-KAT & 20764 & http://www.mpiz-koeln.mpg.de/GABI-Kat/ \\
\hline FLAG & 11500 & http://flagdb-genoplante-info.infobiogen.fr/ \\
\hline
\end{tabular}

A variety of approaches are used to clone and gather information about the function(s) of gene(s). Among these, insertional mutagenesis has been extensively used for cloning genes, promoters, enhancers and other regulatory sequences from Arabidopsis. In this review, we highlight the significance of insertional mutagenesis in functional genomic studies and compile the developments on cloning, characterization and identification of genes and promoter elements in A. thaliana, using the T-DNA tagging strategy. In addition to describing the various experimental approaches, we also point out some of the common difficulties and problems associated with the methodology.

Strategies used for cloning and characterization depend upon the information available about the gene or its product. The information, which can be exploited, includes thespatial and temporal expression patterns of a gene; for example, the presence of its mRNA and/or protein in different cell types, during development, during pathogen infection, or in different environments will have to be examined. Expressed sequence tags (EST's) and microarray-based techniques (Cooke et al. 1996; SinghGasson et al. 1999) are some of the powerful approaches in this direction. Methods utilizing the tools of proteomics (Kmieciak et al. 2002; Borner et al. 2003) like SDS-PAGE, MS (Kawamura and Uemura, 2003), MALDI-TOF (Chivasa et al. 2002; Egelhofer et al. 2002; Fukao et al. 2002; Bae et al. 2003), Yeast two-hybrid system (Teige et al. 2004) etc. have proved very useful in elucidating gene function (Bouchez and Hofte, 1998). Gene suppression (deletion / mutation knock out) or over-expression permits the gene sequence to be linked to a phenotype from which the function of the gene can be deduced (Matzke and Matzke, 1995). TILLING (Targeting Induced Local Lesions In Genomes), another strategy involves traditional chemical mutagenesis followed by high throughput screening for point mutations (McCallum et al. 2000a; McCallum et al. 2000b; Perry et al. 2003; Till et al. 2003; Henikoff et al. 2004) and allows identification of allelic series of induced point mutations in genes of interest. Conversely map based cloning is another tool to identify a gene known only by its phenotype (Komori et al. 2004; Ohno et al. 2004; Sun et al. 2004).

Gene disruption is a powerful tool for obtaining knock out mutants that helps in ascertaining biological function of the numerous uncharacterized open reading frames (ORF's), revealed by the genome sequencing project or represented in expressed sequence tags. Gene knock out systems provide a direct route to determining function. Most other approaches to gene function are correlative and do not necessarily prove a causal relationship between gene sequence and function. For example, DNA chips provide an exciting means to discover conditions under which gene expression is regulated on a genome wide scale (Becker et al. 2003; Birnbaum et al. 2003). However, because factors other than mRNA level also determine the activity of a gene product in situ, expression studies even when done on a genome wide scale cannot prove a causal relationship. By contrast, the availability of a null mutation for the gene of interest allows one to directly monitor the effect of this deficiency on the organism's ability to function. Whereas gene replacement through homologous recombination is now a routine in yeast and mice, in plants exploiting homologues recombination for targeted insertion has not been easy. Although Terada et al. (2002) describe a strategy to achieve homologous recombination in rice, the procedure needs further refinement for routine application in plants. Antisense or over expression is another strategy, to identify gene function through interference. However, it is a laborious approach and results are often inconclusive or impossible to interpret (Azpiroz-Leehan and Feldmann, 1997). Recent reports of successful use of double stranded RNA mediated interference (RNAi) approach in C. elegans (Ashrafi et al. 2003; Kamath and Ahringer, 2003), Arabidopsis (Wang and Waterhouse, 2001; Masclaux et al. 2004) is certain to open new vistas for sequence- specific inhibition of gene function in Arabidopsis (Tuschl, 2003).

Mutational approaches have been successfully usedfor the study of genetic and molecular bases for many traits in plant biology. Access to the mutation is obtained using positional cloning strategies. This strategy is facilitated in model species such as Arabidopsis, for which dense genetic maps with many visible and molecular genetic markers exist, and for which complete physical map consisting of a collection of overlapping cloned DNA fragments and total genome sequence are already available. The limiting factors for this approach are the time and effort required for creating the mapping population and the fine mapping of the mutant locus. 
Table 3. Functionally characterized genes from Arabidopsis using T-DNA.

(a). Forward genetic approach.

\begin{tabular}{|c|c|c|c|}
\hline S. No. & Genes & Functions & References \\
\hline 1 & GL1 & Trichome development & Marks and Feldmann, 1989 \\
\hline 2 & CPR-20 & Disease resistance signalling & Silva et al. 1999 \\
\hline 3 & GI & Phytochrome signalling & Huq et al. 2000 \\
\hline 4 & MYB75 & Anthocyanin production & Borevitz et al. 2000 \\
\hline 5 & LEP & Leaf development & Van der Graaff et al. 2000 \\
\hline 6 & DPE1 & Starch breakdown & Critchley et al. 2001 \\
\hline 7 & Dfl1 & Auxin control of root development & Nakazawa et al. 2001 \\
\hline 8 & KAN & Organ polarity & Kerstetter et al. 2001 \\
\hline 9 & BRS1 & Brassinosteroid signaling & Li et al. 2001 \\
\hline 10 & QUA1 & Biosynthesis of pectins & Bouton et al.2002 \\
\hline 11 & ATE1 & Leaf senescence & Yoshida et al. 2002 \\
\hline 12 & PRPS17 & Leaf senescence & Woo et al. 2002 \\
\hline 13 & PLS & $\begin{array}{l}\text { Auxin-cytokinin homeostasis to modulate root growth and } \\
\text { leaf vascular patterning }\end{array}$ & Casson et al. 2002 \\
\hline 14 & CPL1 and CPL3 & Abiotic stress signalling growth and development & Koiwa et al. 2002 \\
\hline 15 & OSM1 and SYP61 & Stress tolerance and $\mathrm{ABA}$ regulation of stomatal response & Zhu et al. 2002 \\
\hline 16 & HCF152 & RNA processing & Meierhoff et al. 2003 \\
\hline 17 & EXO & Cell division & Farrar et al. 2003 \\
\hline 18 & OMT1 & Lignin and synapoyl ester biosynthesis & Goujon et al. $2003 b$ \\
\hline 19 & ULI3 & UVB light response & Suesslin and Frohnmeyer, 2003 \\
\hline 20 & TPT & Acclimation of photosynthesis to environment & Walters et al. 2003 \\
\hline 21 & AMS & Tapetal and Microspore development & Sorensen et al. 2003 \\
\hline 22 & BXL1 & cell wall metabolism & Goujon et al. 2003a \\
\hline 23 & Cpn60 beta & Molecular chaperonin & Ishikawa et al. 2003 \\
\hline
\end{tabular}

\section{T- DNA tagging}

The use of insertional mutagenesis in principle provides a more rapid way to clone a mutated gene. DNA elements that are able to insert at random within chromosomes such as transposons (Sundaresan et al. 1995; Martienssen, 1998) or the T-DNA of Agrobacterium tumefacians (AzpirozLeehan and Feldmann, 1997), can be used as mutagens to create loss of function mutations in plants. Since the sequence of the inserted element is known, the gene in which the insertion has occurred can be recovered, using various cloning or PCR-based strategies. An advantage of using T-DNA as the insertional mutagen as compared to transposons is that the T-DNA insertions do not transpose subsequent to insertion and are chemically and physically 
Table 3. Functionally characterized genes from Arabidopsis using T-DNA.

(b). Reverse genetic approach.

\begin{tabular}{|c|c|c|c|}
\hline S. No. & Genes & Functions & References \\
\hline 1 & PGP1 & Photosynthesis & Hagio et al. 2002 \\
\hline 2 & SEC and SPY & Gametogenesis and embryogenesis & Hartweck et al.2002 \\
\hline 3 & PGP1 & Photosynthesis & Hagio et al. 2002 \\
\hline 4 & AMT1;1 & NH4+transporter & Kaiser et al. 2002 \\
\hline 5 & LACS9 & Chloroplast Acyl-coenzyme A (CoA) synthetase & Schnurr et al. 2002 \\
\hline 6 & DIR1 & systemic resistance signalling & Maldonado et al. 2002 \\
\hline 7 & GEM1-1 and GEM1-2, & cytokinesis & Twell et al. 2002 \\
\hline 8 & ECA1 & $\mathrm{Ca}^{2+}$ pump & Wu et al. 2002 \\
\hline 9 & MRE11 and KU70 & Telomere maintenance and DNA repair & Bundock and Hooykaas, 2002 \\
\hline 10 & IRT1 & Metal transporter & Henrique et al. 2002 \\
\hline 11 & AtTOP6B & DNA replication & Hartung et al. 2002 \\
\hline 12 & MMT & Selenium volatalisation & Tagmount et al. 2002 \\
\hline 13 & RCN1 & ABA signal transduction & Kwak et al. 2002 \\
\hline 14 & CKI1 & Megagametophyte development & Pischke et al. 2002 \\
\hline 15 & MMP & Flowering and early senescence & Golldack et al. 2002 \\
\hline 16 & AtOPT3 & Embryo development & Stacey et al. 2002 \\
\hline 17 & AtpOMT1, AtpDCT1, AtpDCT2 & Oxoglutarate/Malate and Dicarboxylate Transporters & Taniguchi et al. 2002 \\
\hline 18 & PEX10 & Peroxisome biogenesis & Schumann et al. 2003 \\
\hline 19 & UVH6 & DNA repair (UV resistance) and growth & Liu et al. 2003 \\
\hline 20 & UGT73C6 and UGT78D1 & Flavonol glycoside biosynthesis & Jones et al. 2003 \\
\hline 21 & CAP-E1 & Embryogenesis, meosis and Meristem organization & Siddiqui et al. 2003 \\
\hline 22 & LUT1 & Carotenoid hydroxylase & Tian et al. 2003 \\
\hline 23 & SCD1 and Arp2/3 & Polar cell expansion & Falbel et al. 2003; Li et al. 2003 \\
\hline 24 & CLAVATA1 & Organ development & Dievart et al.2003 \\
\hline 25 & ATHB5 & Abscisic acid signal transduction & Johannesson et al. 2003 \\
\hline 26 & TDS4 & Anthocyanidin synthesis & Abrahams et al. 2003 \\
\hline 27 & AtFUT1 & Xyloglucan fucosilation (cell wall biosynthesis) & Perrin et al. 2003 \\
\hline 28 & ARR15 & Cytokinin mediated signal transduction & Kiba et al. 2003 \\
\hline 29 & ATM & Meiosis and somatic response to DNA damage & Garcia et al. 2003 \\
\hline
\end{tabular}




\begin{tabular}{|l|l|l|l|}
\hline 30 & MAF2 & Vernalisation & Ratcliffe et al. 2003 \\
\hline 31 & Apyrases (Atapy1, Atapy2) & Pollen germination & Steinebrunner et al. 2003 \\
\hline 32 & GORK & Stomatal movements and transpiration & Hosy et al. 2003 \\
\hline 33 & FATB & Fatty acid biosynthesis & Bonaventure et al. 2003 \\
\hline 34 & GGAT & Photorespiration & Igarashi et al. 2003 \\
\hline 35 & ACT7 & Germination and root growth & Gilliland et al. 2003 \\
\hline 36 & PIP2;2 & Hydraulic conductivity of roots & Javot et al. 2003 \\
\hline 37 & ADA2b and GCN5 & Growth, development, and gene expression & Vlachonasios et al. 2003 \\
\hline
\end{tabular}

stable through multiple generations. The T-DNA not only disrupts the expression of the gene into whichit is inserted, but alsoacts as a marker for subsequent identification of the mutation. Since Arabidopsis introns are small and there is very little intergenic material, the insertion of a piece of TDNA on the order of 5 to $25 \mathrm{~kb}$ in length generally produces a disruption of gene function. If a large enough population of T-DNA transformed lines is generated, there are reasonably good chances of finding a transgenic plant carrying a T-DNA insert within any gene of interest. Mutations that are homozygous lethal can also be obtained and maintained in a population in the form ofheterozygous plants. Low copy number and random nature of insertions are considered to be the advantages of T-DNA induced mutagenesis approach.

Extensive work in T-DNA tagging of Arabidopsis has become possible because of improvements in techniques for Agrobacterium mediated transformation. The original root explant method of Valvekens et al. (1988) allowed one to isolate a few transformed plants, via a laborious tissue culture process. Tens of thousands of transformed plants were beyond reach, until Feldmann and Marks (1987) devised a method for producing independent T-DNA transgenic lines via seed transformation. The development of transformation methods based on dipping whole plants into Agrobacterium suspensions has made it possible to generate hundreds of thousands of insertional mutations necessary for saturation of the genome while minimizing the effect of somaclonal variation associated with the process of in vitro culture and regeneration (Clough and Bent, 1998).

\section{Forward and reverse genetics using T-DNA insertion lines}

The advantage of T-DNA over classical mutagens is that the Arabidopsis sequences flanking the insertion site can be isolated easily. This simplifies the identification of genes corresponding to interesting mutants. When screening populations that have been mutagenised with an insertion element, not all of the new phenotypes will be due to insertion mutations. It is important to establish linkage between the mutant phenotype and the insertion element. Even if some linkage can be established, this does not exclude the possibility that the phenotype is caused by a nearby but independent mutation. Consequently it is necessary to identify the gene disrupted by the insertion and test for complementation of the mutant phenotype by the wild type allele in transgenic plants. Because it is not difficult to identify sequences flanking insertion sites, it is reasonable to dispense with co-segregation testing, and proceed directly to identify the gene interrupted by the insertion, followed by a test for complementation of the mutant phenotype by the wild-type version of the gene. Such complementation data provide definitive proof that the phenotype of interest is in fact caused by the insertion mutation. Another way of confirming the same would be by characterizing an independent mutation in the same gene displaying an identical phenotype. Allelism tests can be used with any recessive mutants exhibiting the same phenotype.

A variety of strategies have been devised to generate and isolate mutants in known genes of Arabidopsis by T-DNA or transposon insertional mutagenesis. In these methods, large populations of tagged mutants are generated, which can then be screened for insertions in specific genes. Alternatively, the insertion tags can be individually sequenced and compiled in databases that can be searched for a gene disruption event of interest. This is becoming easier now as genomic sequences of many insertion sites are becoming available (Parinov et al. 1999; Qin et al. 2003).

A highly efficient procedure for obtaining mutants in genes identified in sequencing programs takes advantage of the availability of large collections of plants mutagenised by an insertion element. This procedure makes use of the specificity and sensitivity of the PCR reaction to screen for insertions within regions of interest in a large population of mutagenised plant lines (Young et al. 2001). Using oligonucleotide primers from the insertion element and from the gene of interest, it is possible to detect an insertion event within the gene, even in case of a pooled DNA sample. The sensitivity of the PCR is so high that it is 
Table 4. Genes cloned by activation tagging.

\begin{tabular}{|c|c|c|c|}
\hline Phenotype & Gene & Homology & Reference \\
\hline Shooting induction & CKI1 & Histidine kinase & Kakimoto, 1996 \\
\hline Early flower induction & Flowering LocusT (FT) & Meristem identity gene LEAFY & $\begin{array}{l}\text { Kardailsky et } \\
\text { al.1999 }\end{array}$ \\
\hline Leaves without petiole & Leafy Petiole, LEP & AP2/EREBP family & $\begin{array}{l}\text { Van der Graaff } \\
\text { et al. } 2000\end{array}$ \\
\hline $\begin{array}{l}\text { Suppresses late flowering in winter } \\
\text { annual ecotypes }\end{array}$ & AGL20 & MADS-domain gene & Lee et al. 2000 \\
\hline Wide heart shaped ovary, larger siliques & CYP7889 & Cytochrome P450 & $\begin{array}{l}\text { Ito and } \\
\text { Meyerowitz, } \\
2000\end{array}$ \\
\hline $\begin{array}{l}\text { Intense purple pigmentation in } \\
\text { vegetative organs }\end{array}$ & $\begin{array}{l}\text { pap1-D (production of anthocyanin } \\
\text { pigment1 Dominant) }\end{array}$ & MYB transcription factor & $\begin{array}{l}\text { Borevitz et al. } \\
2000\end{array}$ \\
\hline $\begin{array}{l}\text { Stiff inflorescence stem, thicker leaves, } \\
\text { larger seeds }\end{array}$ & Sturdy & Patatin & $\begin{array}{l}\text { Huang et al. } \\
2001\end{array}$ \\
\hline $\begin{array}{l}\text { Constitutive expression of a number of } \\
\text { key defense marker genes }\end{array}$ & ADR1 & PR-(pathogenesis related) & $\begin{array}{l}\text { Grant et al. } \\
2003\end{array}$ \\
\hline $\begin{array}{l}\text { Attenuated red and far-red } \\
\text { photoresponses. }\end{array}$ & COG1 & $\begin{array}{l}\text { Dof family of transcription } \\
\text { factors }\end{array}$ & Park et al. 2003 \\
\hline $\begin{array}{l}\text { Shoot formation in the absence of } \\
\text { exogenous cytokinins }\end{array}$ & AtIPT8 & isopentenyl transferase & Sun et al. 2003 \\
\hline Dwarf & AtGA2ox7 AtGA2ox8 & Gibberellin 2oxidases & $\begin{array}{l}\text { Schomburg et } \\
\text { al. } 2003\end{array}$ \\
\hline
\end{tabular}

possible to detect such an event in large pools (up to a few thousand) of mutagenised plants (Bouchez and Hofte, 1998). The pool is then repeatedly subdivided until a single plant carrying the desired insertion is identified. The identified mutant plants are then tested for phenotypes that are predicted to result from loss of function of the gene. This is becoming easier now as genomic sequences of many insertion sites are becoming available (Parinov et al. 1999; Qin et al. 2003). Winkler et al. (1998) have developed an efficient reverse-genetics protocol that uses expedient pooling and hybridization strategies to identifyindividual transfer-DNA insertion lines. They have screened a collection of 6000independently transformed lines using this protocol to systematically isolateArabidopsis lines containing insertional mutations in individualcytochrome P450 genes.

Feldmann (1991), after segregation analysis of a large number of transformants, concluded that the average number of independent inserts is 1.5 per diploid genome with $57 \%$ of the transformants containing a single insert and $25 \%$ containing two. Also within the context of the target gene, insertion appeared to be random, as T-DNA inserts were found in exons, introns, and in the 5' and 3' flanking regions of the more than 30 genes that were characterized. In addition, after screening of the first 14000 transformants no obvious hotspots for insertion of T-DNA were detected (Azpiroz-Leehan and Feldmann, 1997). However, genome wide analysis of the distribution of integration sites conducted by Alonso et al. (2003) on a TDNA mutagenised population of Arabidopsis revealed the existence of a large integration site bias at both chromosome and gene levels. Alonso et al. (2003) generated over 225000 independent T-DNA insertions, representing near saturation of the entire gene space, out of these, locations of 88,000 insertions were precisely identified. This study conducted at the Salk institute of biological studies, La Jolla CA, USA lead to creation of mutants in $\sim 73 \%$ of predicted Arabidopsis genes. The number of integrations was reported to decrease dramatically from the gene rich chromosome arms towards the centromeres.And at the gene level a significant bias was observed against integration events in exons and introns, in favour of 5'UTR, 3' UTRs and promoters. A similar observation was made by the German plant genomics research programme GABI-KAT. The GABI-KAT 
Table 5. Promoter elements cloned using promoter trap vectors.

\begin{tabular}{|l|l|l|l|l|}
\hline S.No. & \multicolumn{1}{|c|}{ Promoter } & \multicolumn{1}{|c|}{ Specificity of expression } & Source species & \multicolumn{1}{|c|}{ Reference } \\
\hline 1 & At EM & Embryo & Arabidopsis & Topping et al. 1994 \\
\hline 2. & Cryptic & Seed coat specific & Nicotiana tabacum & Fobert et al. 1994 \\
\hline 3 & HVT1 & Tapetum and vascular tissue & Arabidopsis & Wei et al. 1997 \\
\hline 4 & Pyk20 & Nematode feeding structure & Arabidopsis & Puzio et al. 1999 \\
\hline 5 & tcup & Constitutive & Nicotiana tabacum & Foster et al. 1999 \\
\hline 6 & Cryptic & Guard Cell & Arabidopsis & Plesch et al. 2000 \\
\hline 7 & Cryptic & Roots & Arabidopsis & Mollier et al. 2000 \\
\hline 8 & Lj Cbp 1 & Roots & Lotus Japonicus & Webb et al. 2000 \\
\hline 9 & elF-4A1 & Growing tissues, young leaves & Arabidopsis & De Greve et al. 2001 \\
\hline 10 & EXORDIUM (EXO) & Meristematic cells & Arabidopsis & Farrar et al. 2003 \\
\hline
\end{tabular}

population of T-DNA mutagenised Arabidopsis thaliana lines with sequence-characterized insertion sites is being used extensively for efficient progress in plant functional genomics. After PCR-based amplification of DNA fragments spanning insertion site borders and sequencing, the data were placed in a flanking sequence tag (FST) database describing which mutant allele was present in which line. Analysis of the distribution of T-DNA insertions revealed a clear bias towards intergenic regions. Insertion sites appeared more frequent in regions in front of the ATG and after stop codons of predicted genes (Rosso et al. 2003).

\section{Channelling genome resources for public use}

Large collections of the T-DNA insertion lines are being provided to the Arabidopsis stock centres at Ohio State University (USA) and Nottingham (UK) by the individuals/groups who constructed them. More than 175,000 T-DNA insertion lines of various types are already available from the Arabidopsis Biological Resource Center (ABRC). Table 1 represents the lists of T-DNA insertion lines generated by various groups and are available with different centers. The non-profit organizations can obtain these lines for a fee of $£ 2.25$ ( $£ 8.50$, additional charge) from NASC (Nottingham Arabidopsis Stock Center also known as the European Arabidopsis Stock Center) and \$4 ( $\$ 15$, additional charge), from ABRC. The fee structure for a profit organization for obtaining a line is four times than that of non-profit organization. ABRC sends the stock free of charge to any laboratory that cannot afford the associated charge. The stock centres have a distribution agreement. According to which, North and South American users are expected to order seed stocks from ABRC, and European users are expected to order seed stocks through NASC. The laboratories in other locations may order seed stocks from

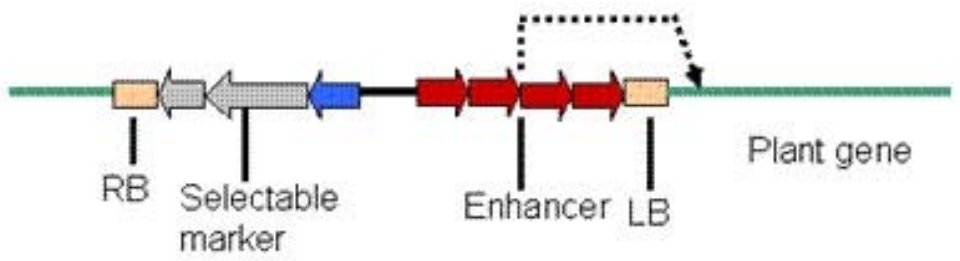

Figure 1. Activation tag vector. The vector contains multimerized auliflower Mosaic Virus (CaMV) $35 \mathrm{~S}$ enhancer that can function in either orientation and can cause transcriptional activation of nearby genes resulting in dominant gain of function mutations. RB and LB represent right and left borders of T-DNA, respectively. The activation of plant gene by enhancer elements is indicated by broken arrow (black). The flanking plant DNA is shown in green. 


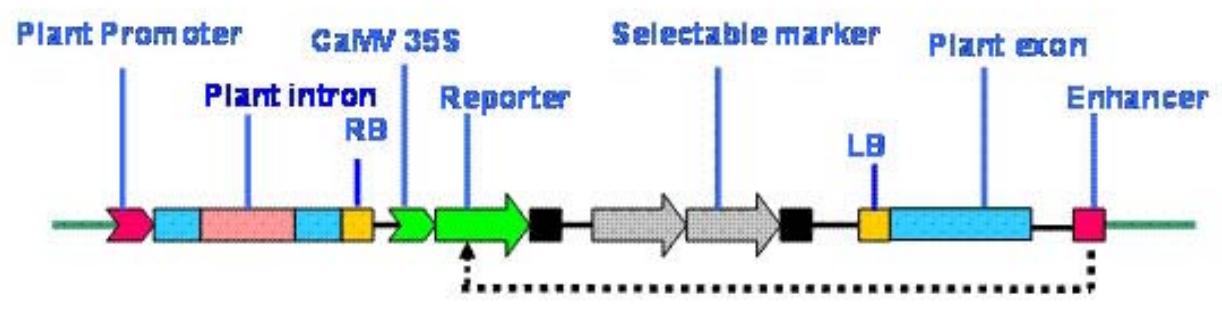

Figure 2. Enhancer trap. The minimal promoter of the reporter gene is activated by a chromosomal enhancer element, resulting in over-expression of the reporter gene. The activation of reporter gene by enhancer is indicated by broken arrow (black).

either centre. A number of lines require the signing of a material transfer agreement (MTA). For obtaining GABIKat T-DNA lines the costs is $€ 499 /$ - per line for academic institutions and are available only for research purposes. However, for profit institutions a contract needs to be set up between the company and Garching Innovation (the MPG technology transfer organisation).

Furthermore several groups are working to isolate and sequence DNA fragments flanking insertion sites and are depositing sequences in databases. When these databases reach sufficient size, it will be, possible to find an insertion in any gene of interest simply by consulting the databases and ordering seed from the stock centre. Systematic sequencing of insertion sites in various populations have been initiated by several group (Krysan et al. 1999; Speulman et al. 1999; Tissier et al. 1999; Galbiatiet al. 2000; Brunaud et al. 2002; Samson et al. 2002; Session et al. 2002; Szabados et al. 2002; Qin et al. 2003; Ostergaard and Yanofsky, 2004). Table 2 provides the list of variety of databases from where users can access the information regarding the T-DNA insertion lines.

Recently 150,000 transformed plants carrying 225,000 (1.5 insertion per line) independent T-DNA integration events was generated and precise locations determined for $>88,000$ loci by the Salk Institute of Biological Studies (Alonso et al. 2003). Analysis of the insertion site sequences revealed that insertional mutations had been created in $\sim 74 \%$ of the annotated Arabidopsis genes.

Surprisingly, although PCR based reverse genetic screens have been available to Arabidopsis researchers, for several years, relatively few informative knockouts obtained in Arabidopsis have given rise to a visible, directly scorable phenotypes. Several reports have shown that this lack of phenotypes is presumably because of partial and complete functional redundancy besides the ability of higher plants to adapt their physiology to various stresses and constraints without undergoing morphological changes, and by our inability to detect slight physiological alterations and/or weak reductions in fitness (Bouche and Bouchez, 2001). In order to identify conditional phenotypes, the mutants have to be tested under a wide range of environmental conditions (Meissner et al. 1999), as plants being sessile organisms have evolved many adaptive traits that allow them to cope with changes in their biotic and abiotic environment. Many loss of function mutants are therefore expected to be conditional and revealed only by a specific combination of environmental parameters.

Using T-DNA tagging several genes have been identified and cloned. Table $3 \mathrm{a}$ and $3 \mathrm{~b}$ provide a list of genes cloned in Arabidopsis using T-DNA tagging in the recent years, using forward and reverse genetic approaches, respectively.

\section{SPECIFIC USES OF T-DNA LINES USING SPECIALIZED VECTORS}

Simple insertional mutagenesis, like all gene disruption approaches, has some limitations. It is difficult to identify the function of redundant genes or of genes required in early embryogenesis or gametophytic development. To overcome these limitations modified insertional elements have been developed.

Activation trap, enhancer trap and gene / promoter trap vectors are specialized versions of insertional mutagens. In addition to screens for loss of function phenotypes, gene function can also be identified based on expression patterns or gain-of-function phenotypes. These screens are particularly useful for genes that have redundant and multiple functions during development.

\section{Activation tagging}

Enhancer and gene trap insertions identify genes on the basis of their expression pattern. In activation tagging insertion alleles are generated using T-DNA or transposons that carry either a constitutive promoter such as CaMV $35 \mathrm{~S}$ (Wilson and Somerville, 1995) or multimeric enhancers from the CaMV $35 \mathrm{~S}$ promoter (Weigel et al. 2000). Because enhancers can function in either orientation and at a considerable distance from the coding regions, they can cause transcriptional activation of nearby genes, resulting in dominant gain of function mutations (Figure 1). Such gene activation may produce novel phenotypes that are either redundant members of a gene family or are essential for survival. Activation tagging strategy, developed by Walden et al. (1994) has been used to generate collections of morphologically diverse dominant mutants resulting in cloning of corresponding genes (Table 4). 


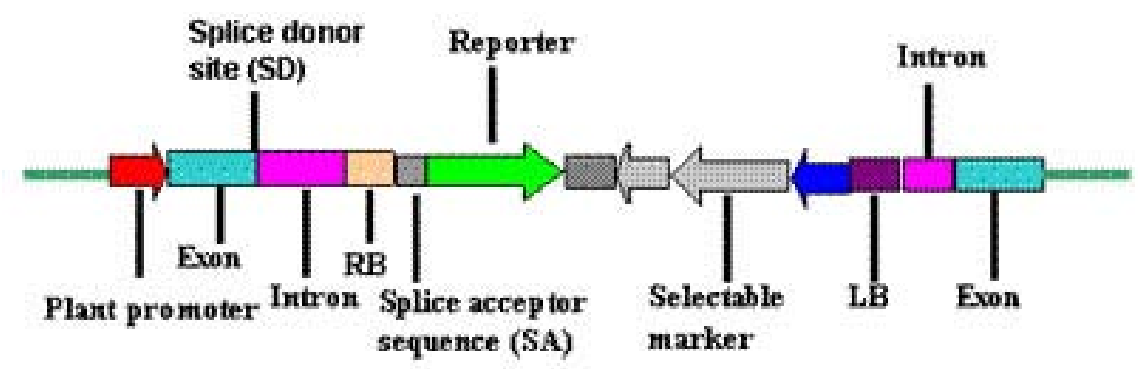

Figure 3. Gene trap vector. The promoterless reporter gene contains splice acceptor (SA) sequence. The promoterless reporter gene can be expressed when insertion of a promoter trap vector occurs in an intron and results in a transcriptional fusion due to splicing from the chromosomal splice donor (SD) site to the SA sequence.

Although the paper published by Walden et al. (1994) was later retracted as the major findings of the work could not be substantiated. However, the basic procedure, namely activation tagging described by these workers is a valid technique and is has been used by other workers (Balter, 1999). Majority of the on gain of function mutations are on alterations of phenotypes related to plant defence responses (Weigel et al. 2000). More recently 45000 T-DNA insertion lines were generated using an activation tag vector. Out of the 1194 T-DNA insertion sites 1010 have their tags inserted in or close to a predicted gene and nearly half of these genes were those with unknown functions (Qin et al. 2003). The interfered genes were distributed in all five chromosomes and were involved in a variety of processes including metabolism, transcription, plant defence, signal transduction etc.

\section{Promoter and enhancer trap vectors}

With the ever increasing reports of creation of transgenic in various crop plants, the search for novel genes and variety of regulatory elements of DNA required for controlled expression of the introduced genes is gaining more importance. Regulatory elements that impart a tissuespecific, stage-specific and/or environmental-stimulispecific expression to the transgene are being identified and cloned using T-DNA based vectors that have been designed to identify and clone such regulatory sequences.

The general principle behind this approach is to integrate a reporter gene that either lacks a promoter (gene/promoter trap) or carries only a minimal promoter (enhancer trap), at random sites in the wild type genome. A reporter gene cassette containing a minimal promoter (enhancer trap) close to the end of the insertion element can be cis activated when inserted close to a transcriptional enhancer that will drive the expression of the reporter gene (Figure 2). The gus (uid A) reporter gene is the most commonly used reporter gene system in plants, because of the absence of endogenous $\beta$-glucuronidase (GUS) activity in most plants and the opportunity to visualize the presence of the enzyme by sensitive histochemical techniques (Jefferson et al. 1987).

Mutagenised populations can be screened for lines expressing reporter gene in specific cell types or in specific environmental conditions. Genes with interesting expression patterns and their promoters can be isolated from such lines. Small populations of promoter trap lines have been generated in our laboratory using promoter trap vectors carrying promoterless GUS gene (Resminath et al. 2005). The T-DNA tagged lines generated are being used for identifying novel genes and tissue specific promoters. Apart from the ease of identifying redundant genes this method helps detection of insertions in UTR's. An insertion in the 3' UTR's of genes generally will not lead to suppression of gene expression as the coding region remains intact, but can lead to reporter gene expression enabling detection of the otherwise hidden mutation. Repeated observations of a significant bias towards T-DNA integration in promoters and UTR's (Alonso et al. 2003; Qin et al.2003) justify a high frequency of GUS expressing lines in the mutant population.

Promoter trap lines can also be exploited to mark certain cell types for developmental studies (Sundaresan et al. 1995). Enhancer traps allow an ingenious way of identifying genomic sequences expressed in precise developmental patterns. In the case of GUS as the reporter gene, the presence of GUS activity in a particular organ or cell at a particular developmental stage will identify sequences expressed at this place and time. Indeed, GUS enhancer traps have proved successful in detecting novel genes in Arabidopsis. A disadvantage, however, is that it may not be easy to identify and locate the enhancer causing the specific expression pattern, since the enhancer element could be in either side of the T-DNA and could also be at a far off distance.

Plants for mutant screens are usually grown from $T_{2}$ seed because most mutant phenotypes result from homozygous recessive mutations and first generation of mutagenised plants, which will be heterozygous for induced mutations, will not show mutant phenotype. The $T_{1}$ generation of $T$ DNA mutants can be screened for dominant mutation, as these plants are hemizygous for the insertions. Hemizygotes arise because the ovule is the target (Ye et al. 1999) for TDNA transformation of flowers. Thus, the $T_{1}$ generation seeds obtained after Agrobacterium mediated floral dip transformation method can be used for the screening of 


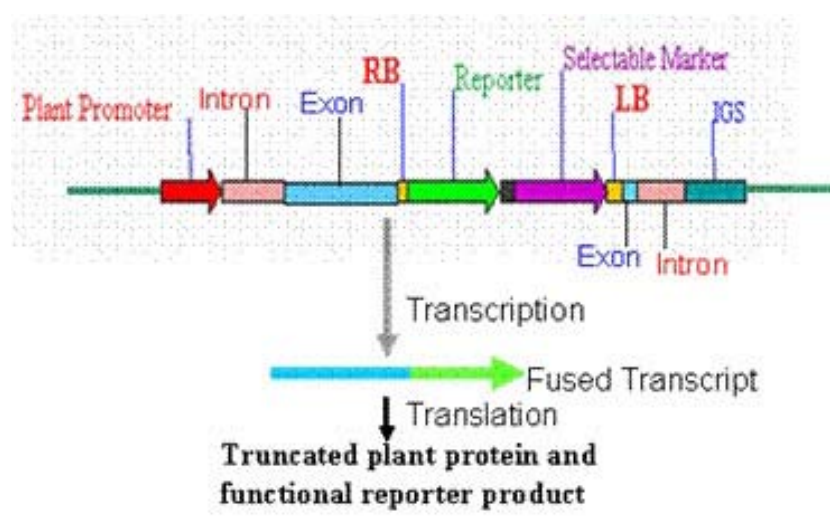

Figure 4. Prompter trap. The promoterless reporter gene can be expressed when insertion of a promoter trap vector occurs in an exon so as to result in a transcriptional fusion and disruption of native gene product.

activation tag, gene-trap, and enhancer trap lines.

In the gene/promoter system (Figure 3 and Figure 4), insertion of the promoter-less reporter not only disrupts normal gene function but also activates expression of the reporter gene. Because expression can be monitored in heterozygous plants, gene trap system is useful for studying expression patterns of most plant genes, including essential genes that cause lethal mutations. This system is convenient for observing mutant phenotypes because reporter activation indicates the location, condition and the time of expression for the disrupted gene. In Arabidopsis, activation of reporter genes has been observed in $\sim 30 \%$ of the transgenic. Some of the recently developed gene trap systems contain an intron with multiple splicing acceptor and donor sites in each of the three reading frames in front of the coding region of the reporter gene (Sundaresan et al. 1995).

These constructs allow reporter gene expression even when the insertion occurs in intron. As a consequence, expression is also observed at high frequencies in Arabidopsis plants transformed with such a gene trap system. Selection or screening for gene specific insertions can also be accomplished independently of promoter activity, as the expression of the marker in the gene trap vector is dependent not only on the activity of an endogenous promoter but also on transcript processing (splicing) and formation of translational fusions (Maes et al. 1999).

Some ten years of promoter trapping experiments show that frequency of reporter gene expression is generally much higher than expected for random integration in the plant genome (Mollier et al. 1995). Promoter trap strategy provides a means of identifying genes, and characterizing in vivo, their expression patterns, throughout the plant life cycle in viable heterozygotes. The insertion of T-DNA into the tagged gene also facilitates its cloning. During the last few years promoter trap lines have proved to be invaluable for the creation of marker lines (Kertbundit et al. 1991) and for the isolation of regulatory sequences and eventually the isolation of specifically expressed genes (Topping et al. 1994; Muskett and Lindsey, 1995; Ferreira da Rocha et al. 1996; Wei et al. 1997) including the isolation of environmental and hormonal stress responsive regulatory sequences and genes (Mandal et al. 1995). The promoter trap approach is particularly relevant to identification and cloning of genes (and their regulatory sequences) expressed in tissues that are difficult to analyze, by traditional methods relying on RNA extraction, as demonstrated by the cloning of regulatory sequences driving reporter gene expression in nematode feeding structures (Barthels et al. 1997) or the identification of molecular markers for embryogenesis (Topping et al. 1994; Topping and Lindsey, 1997).

A T-DNA tagged mutant showing intense GUS expression in young leaves and rapidly growing stem tissues was used to isolate an eukaryotic translational initiation factor $e I F$ 4AI (De Greveet al. 2001) Promoter-like sequences, knownas cryptic promoters which are not associated with a detectable transcript have also been revealed by promoter trapping (Mollier et al. 2000). The popularity of the promoter trap method can be judged from the various collections developed worldwide as well as the variety of reporters and constructs in use. A collection of 20,261 transgenic lines of Arabidopsis generated with the promoter trap vector pTluc, which carries a promoterless firefly luc (luciferase) reporter gene linked to the right T-DNA border is the latest report in line. By detection of bioluminescence in three week-old seedlings, 753 lines were identified showing constitutive, organ-specific, and stress-responsive luciferase expression patterns. Several lines showed sugar, salt, and abscisic acid (ABA)-inducible luciferase activity (Alvarado et al. 2004). Moreover the technique has now been adopted for the ongoing intensive functional genomics efforts in rice demonstrated by the trapping of two cold inducible genes from screening of T-DNA tagged rice lines for cold responsive GUS expression (Lee et al. 2004). Table 5 provides a list of promoter elements cloned using promoter trap vectors. Jeong et al. (2002) have created a total of 13,450 T-DNA insertion lines in rice that could be used to screen for promoter activity as well as for creating gain of function mutants. In addition to the promoter less GUS reporter gene located next to the right border, the binary vector used in the study carries multimerised transcriptional enhancers from the CaMV35S promoter near the left border. Interestingly histochemical GUS assays revealed the GUS-staining frequency in these lines to be about twice as high as that from lines transformed with vectors, which lack the enhancer elements suggesting that enhancer sequence present in T-DNA improves GUS tagging efficiency.

\section{Strategies for isolating and cloning sequences flanking T-DNA}



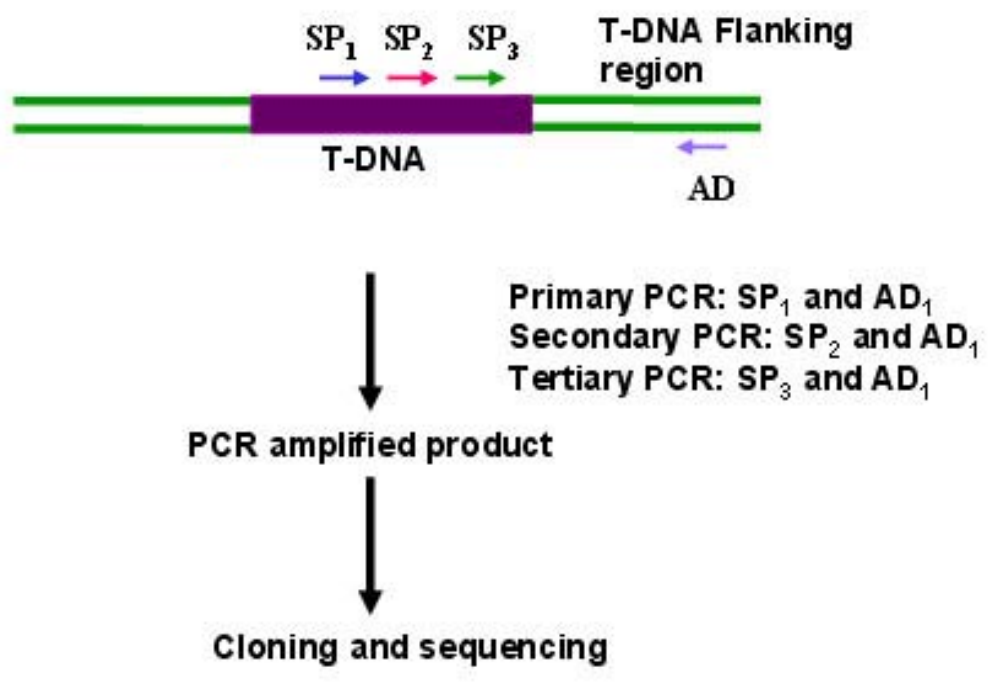

Figure 5. Schematic representation of TAIL PCR. This strategy involves three consecutive rounds of PCR, performed with a set of three nested T-DNA specific primers $\left(\mathrm{SP}_{1}, \mathrm{SP}_{2}\right.$ and $\left.\mathrm{SP}_{3}\right)$ and a small, arbitrary primer. The positions of three nested primers in the TDNA region are indicated by blue, red and green arrows respectively. $A D$ is arbitrary degenerate primer indicated by purple arrow. $T$ DNA flanking region is indicated by green line.

Once co-segregation of T-DNA along with the phenotype has been established for a given mutant, isolation of the disrupted gene can be achieved by a number of strategies. Sequences flanking the insertion can be easily identified from single or low copy number lines using inverse PCR (IPCR) and by thermal asymmetric interlaced (TAIL) PCR (Figure 5). The latter consists of three consecutive rounds of PCR amplification, performed with a set of three nested insertion-specific primers and a small, arbitrary primer, which anneals nearby in the insertion flanking sequence (Liu et al. 1995). Recently, Antal et al. (2004) have reported a simplified version of TAIL PCR called, single oligonucleotide nested (SON)-PCR, which involves only two rounds of PCR with two or three nested sequence primers.

Another strategy employed called, plasmid rescue (Yanofsky et al. 1990; Feldmann, 1992) makes use of insertion within T-DNA of an 'ori' sequence a replication of origin required for replication of plasmids in E. coli, along with a bacterial selection marker. Genomic DNA from mutant plant is digested with an appropriate enzyme and religated at high dilution to favour intramolecular reactions. The ligation products are introduced into $E$. coli and clones are selected on appropriate antibiotic selection. Because of the presence of the proper origin of replication and the presence of bacterial selectable markers, the plasmid is able to replicate in a proper $E$. coli host. The plasmid isolated from such bacteria thus contains the linked plant DNA as a passenger (Figure 6). A similar rationale applies to inverse polymerase chain reaction. In this procedure, plant DNA is digested with a restriction enzyme that cuts within the T-DNA and subjected to self-ligation. The circularized ligation products are subjected to PCR using appropriate primers from the T-DNA such that the flanking plant sequences, which are now part of the circularized product, are amplified (Figure 7).

Adaptor PCR or anchor PCR ligates adaptor molecules to the ends of the digested DNA fragments carrying part of the insert. A primer specific to the adaptor region and nested primers specific to T-DNA are used to amplify the flanking region (Figure 8). This method has been efficiently used in the German plant genome project GABI and flanking sequence database has been created using this data.

There is another simple and efficient PCR strategy to amplify the T-DNA flanking region known as T-linker specific ligation PCR (T-linker PCR) described by Yuanxin et al. (2003). This strategy amplifies the template molecules in three steps. First genomic DNA is digested with 3' overhang enzymes. Secondly, primed with by a specific primer, a strand of target molecule is replicated by Taq DNA polymerase and a single A tail is generated on the 3' unknown end of the target molecule, and then a 3 ' overhang-T linker (named T-linker) is specifically ligated on to the target. Thirdly, the target is amplified by two rounds of nested PCR with specific primers and T-linker primers. It differs from other methods in specific TA ligation instead of arbitrary ligation or random annealing.

Finally one can simply construct a genomic library of the mutant and isolate clones containing T-DNA sequences. Some of these clones will contain plant DNA as well. In any case unequivocal proof about the function of gene is obtained by performing molecular complementation, i.e., by demonstrating that the introduction of a wild type allele would eventually restore the phenotype.

PROBLEMS ASSOCIATED WITH THE T-DNA LINES 


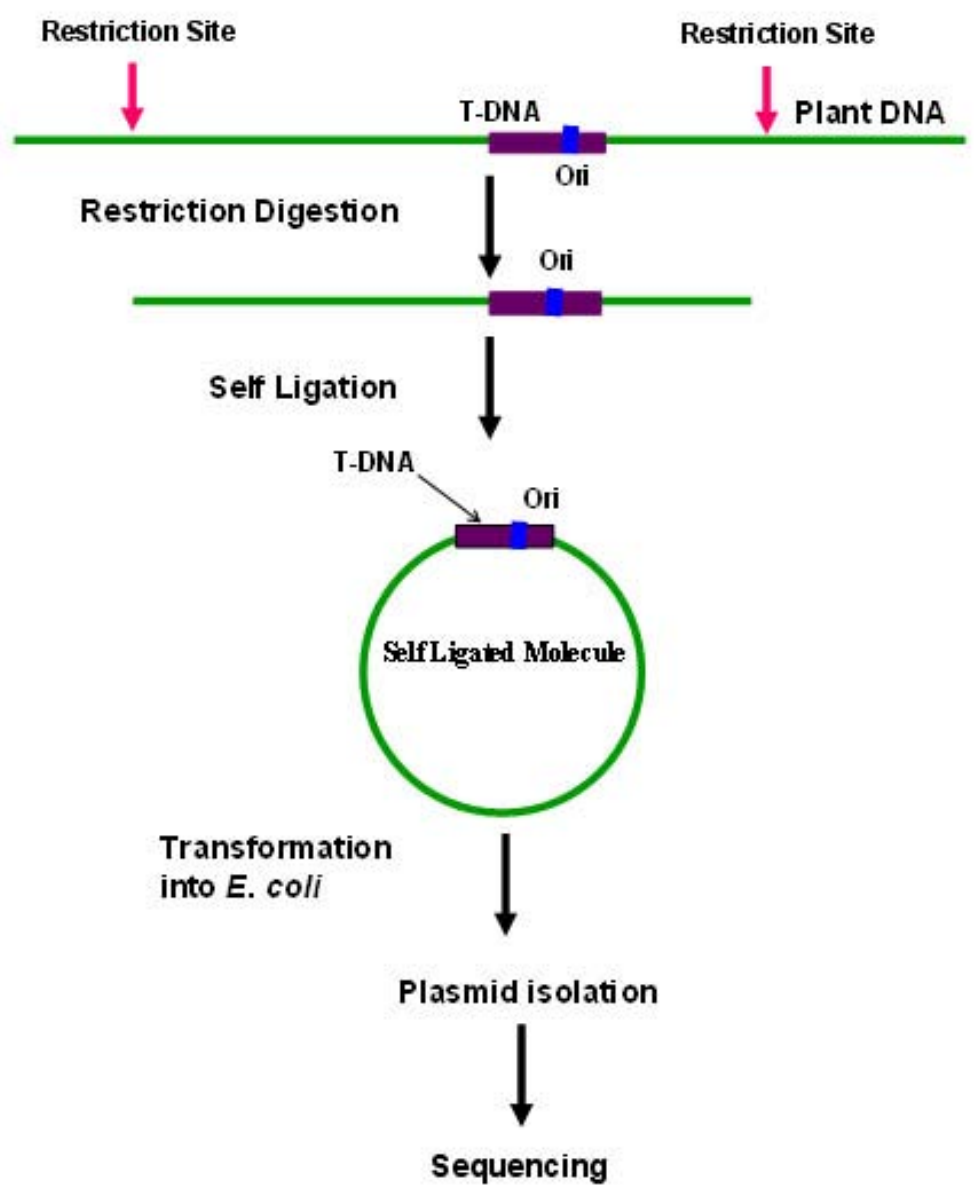

Figure 6. Schematic representation of plasmid rescue. This strategy involves restriction digestion ofgenomic DNA from mutant plant with an appropriate enzyme (preferably with an enzyme which does not cut within the T-DNA). Self ligated molecules are used for transformation of $E$. coli. The self-ligated fragments containing the T-DNA along with the flanking sequences are able to survive and are rescued as plasmid because of the presence of origin of replication (Ori), shown here in blue. The plant DNA is indicated by green line. The restriction sites are shown as red arrows.

A variety of problems are encountered while analyzing the T-DNA tagged lines, in particular while attempts are made to clone flanking sequences from a T-DNA tagged mutant. Difficulty can arise because of multiple insertions, complex arrangement of T-DNA, insertion of vector backbone sequences, chromosomal duplication and rearrangements or a combination of these (Jorgensen et al. 1987, Veluthambi et al. 1988, Tax and Vernon, 2001).

\section{Multiple insertions and complex T-DNA loci}

Complex T-DNA inserts composed of two or more T-DNA repeats are frequently found in transgenic lines (De Buck et al. 1999). Methods like the TAIL PCR allow for the direct identification of insertions sequences co-segregating with the mutant phenotype even in the presence of more than one insertion. The flanking sequences representing the part of the gene of interest can be readily used to identify the corresponding gene from the Arabidopsis genome database.

\section{Transfer of vector backbone}

Although T-DNA tagging and isolation of flanking sequences may appear a rather simple and straight forward method to clone genes and promoters, but the inconsistency in T-DNA integration can complicate efforts to clone and identify adjacent plant DNA. Studies have indicated that Agrobacterium T-DNA can be present in the genomes of transformed host plants as single units or in multiple tandem arrays (Jorgensen et al. 1987). Some of them have also shown the existence of truncated T-DNA regions. TDNA regions beyond the border repeat were also found to be stably integrated into plant genomes at high frequencies. Read through of border sequences during $T$ strand formation in the bacterium has been reported (Stachel et al. 1987; Veluthambi et al. 1988). Even DNA sequences of the vector, from far beyond the defined T-DNA region delimited by the border sequences have been detected. Therefore, flanking sequence amplification from T-DNA tagged mutants has the potential of amplifying considerably larger tags of vector backbone sequences than expected.

This problem can be solved by designing primers outside the T-DNA borders and using special Taq polymerases 


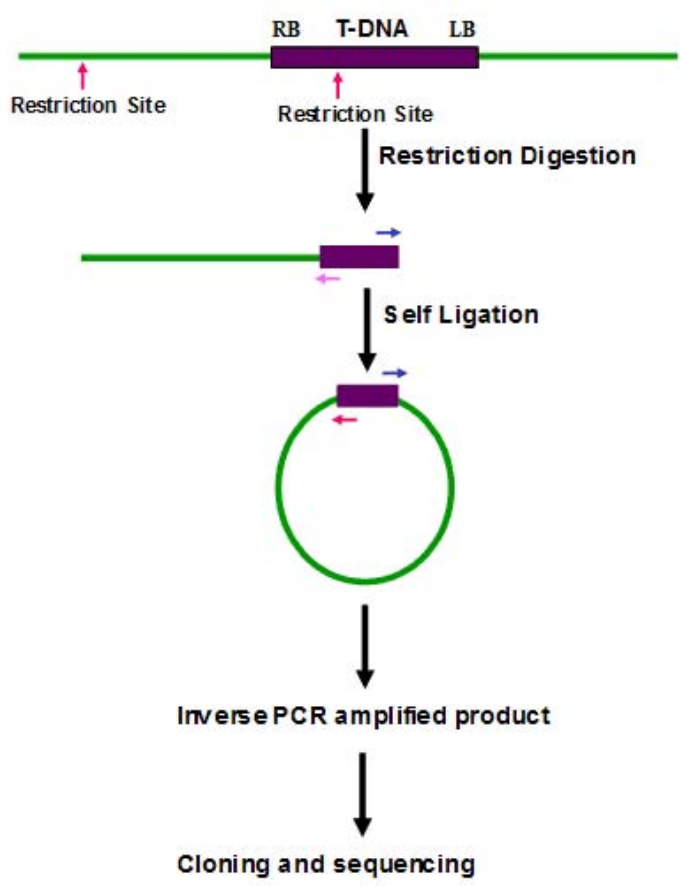

Fig 7: Schematic representation of inverse PCR. This involves restriction digestion ofgenomic DNA from mutant plant with an appropriate enzyme that cuts (preferably cuts once within the T-DNA) followed by self-ligation. The circularized ligation products are used for PCR amplification using appropriate primers from the T-DNA region. The flanking plant DNA is represented by line (green). The appropriate primers (forward and reverse) are indicated by blue and red arrows.

capable of performing long PCR amplification. Long PCR techniques has become routine in most of the large scale TDNA tagging projects owing to the relatively high prevalence of vector backbone sequences in the mutant population. These sequences transfer to the plant either independently of (unlinked to) the T-DNA or linked to the T-DNA across either the left or right T-DNA border. High frequency transfers of sequences beyond the T-DNA border have been reported by Kononov et al. (1997). This work showed that as high as $75 \%$ of transgenic tobacco plants generated using Agrobacterium mediated T-DNA transfer contain binary vector backbone sequences integrated into the plant genome. Therefore, integration of backbone sequences besides the T-DNA sequences into the genomes of plant may also be responsible for causing mutations in TDNA tagged populations. A number of groups have reported that in a large percentage of T-DNA tagged Arabidopsis plants, the T-DNA did not co segregate with the mutant phenotype (Koncz et al. 1989; Errampalli et al. 1991; Feldmann, 1991). In these cases it is possible that the mutation could have been caused by the insertion of backbone sequences independent of the T-DNA in these lines.

\section{Chromosomal duplication/rearrangement}

Internal chromosomal duplication/rearrangements have been identified in the course of both reverse and forwardgenetics approaches. An embryo-defective 88 mutation was characterized with simple T-DNA inserts that exhibited normal Mendelian segregation and detected through a combination of detailed molecular analysis and mapping of the kanamycin-resistance phenotype imparted by the TDNA (Tax and Vernon, 2001). Although emb88is located on chromosome 1, molecular analysis of genomic DNA directly adjacent to the T-DNA left border revealed sequence from chromosome 5. Mapping of the T-DNA confirmed that a $>40 \mathrm{~kb}$ region of chromosome 5 had inserted with the T-DNA into the emb88 locus on chromosome 1. A similar scenario was observed in a reverse-genetic study of the LR-RPK gene. A prospective insertion mutation was identified by PCR screening of TDNA lines. Whereas wild-type LR-RPK is encoded on lower chromosome 4, mapping of the T-DNA localized the mutant allele to chromosome 5. In both these cases, sequence of T-DNA flanking regions did not provide an accurate picture of DNA disruption. Therefore, T-DNA insertion lines- even those that exhibit straightforward genetic behaviour with regard to T-DNA and developmental phenotypes may contain an unexpectedly high frequency of duplication/transpositions. Such rearrangements can interfere with reverse-genetic analyses and provide misleading information on the molecular basis of mutant phenotypes. This would necessitate, genetic mapping of T-DNA insertion sites, in addition to standard genetic and molecular characterization of mutant alleles for meaningful interpretation of phenotypes or sequence information from T-DNA mutant.

\section{Insertional mutagenesis in other angiosperms}

The progress of genomic analysis of plants has made huge leaps in recent years and a large body of information on genomic sequences, sequences of cDNA's and physical maps are now available for several plants including rice, maize, tomato and Brassica. Databases of many if not all, gene sequences of model plants are available and bioinformatics is enabling the prediction of gene function.

On the basis of comparisons among genomes, it is still necessary to validate these predictions. So various methods used for model Arabidopsis genome have been optimized and suitably streamlined for the systematic identification of the biological functions of genes in other more economically important crop species.

Rice genome has been extensively covered because of its small size among cereal genomes, nearly complete genome sequence and economic importance, as a major crop. Maize Ac/Ds transposon system has been proved to be efficient for gene tagging and functional analysis in this crop (Hiroyuki et al. 1999). Kolesnik et al. (2004) has reported a collection of unlinked single copy Ds transformants. Analysis of 2057 Ds flanking sequences has revealed preferential transposition of Ds into regions of genome rich in expressed sequences. This coupled with a high germinal and independent transposition frequency establishes the efficiency of this system for large-scale mutagenesis in rice. 
T-DNA tagging has been used successfully for gene discovery in rice. An initial database has also been constructed using T-DNA flanking sequences (Sha et al. 2004). T-DNA tags have also been observed to insert preferentially into gene rich regions (Chen et al. 2003; Sha et al. 2004). A database of insertion sites in rice is publicly available at $\mathrm{http}: / / \mathrm{www}$. genomics.zju.edu.cn/riceetdna. In addition a rice retrotransposon Tos 17 that is activated in tissue culture has also been used for this purpose.

In tomato new tools for functional analysis based on insertional mutagenesis, with Ac/Ds system in the background of the miniature cultivar Micro-Tom has been established (Meissner et al. 2000). Micro-Tom is well suited for large scale mutagenesis in tomato owing to its small size, rapid life cycle, easy transformability, and efficient activity of the Ac/Ds elements (Meissner et al. 1997). In addition, promoter trapping using firefly luciferase reporter gene and enhancer trapping using GUS was also developed. A high luciferase activity in the flowers, fruits and seedlings (69\%) suggested preferential insertion of Ds elements into genes. Data was also supported by flanking sequence analysis. This well initiated high -throughput functional analysis of genes and promoter isolation in tomato was complemented by a T-DNA insertional mutagenesis programme using activation tagging to identify genes that regulate metabolic pathways, which produced $>10,000$ independent activation tagged transgenic tomato lines and identified large number of leaf and fruit colour mutants. Analysis of an activation tagged insertion line with intense purple pigmentation led to cloning of ANT1 gene, a transcriptional regulator of anthocyanin biosynthesis, modification and transport (Mathews et al. 2003).

T-DNA tagging strategy for isolation of new promoters has been tried in Brassica napus employing hypocotyl transformation with a promoterless gus: nptII tagging construct. This study led to the isolation of new constitutive promoters suitable to drive expression of transgenes in crops as well callus specific promoters that can be used to drive selectable marker genes enabling selection in early phase of transformation procedure and eliminating marker gene products from mature transgenic (Bade et al. 2003). Considering the high efficiency gained by the reverse genetic programs it appears likely that all of the 20,000 to 25,000 genes that make up the basic angiosperm genome will be assigned function on the basis of experimental evidence by the turn of the decade. Understanding the molecular basis of developmental and metabolic diversity among angiosperms is the key to effective and rational improvements in the productivity and utility of crop species (Somerville and Somerville, 1999).

\section{CONCLUDING REMARKS}

The advent of high through put DNA sequencing has meant that the ability to identify genes has far outstripped the ability to determine gene function. The consequently, $90 \%$ of the predicted genes in the Arabidopsis genome are of unknown function. Therefore, an important companion to gene identification are functional genomic investigations aimed at determining the pattern of the expression of genes in the whole organism coupled with assigning functions to individual genes. The use of mutagenesis to find and study plant genes is increasingly being used in functional genomics. T-DNA insertion mutations are a valuable resource for studies of gene function in Arabidopsis, serving as the basis for both forward and reverse genetic strategies and as a source of sequence tags from large collections of mutant lines However mutagenesis allows only partial analysis of genes that function at multiple stages of development, genes that are functionally redundant or highly pleiotropic. Additionally it is difficult to identify genes required in the gametophytic generation. Traps and reporter genes allows for the discovery and analysis of these types of genes also.

Therefore use of activation elements, enhancer traps and promoter traps in gene tagging studies is complementary to loss of function studies, because it provides the opportunity to generate new types of gain of function mutants. Thus promoter traps and enhancer traps provides a means of identifying genes, and characterizing in vivo, their

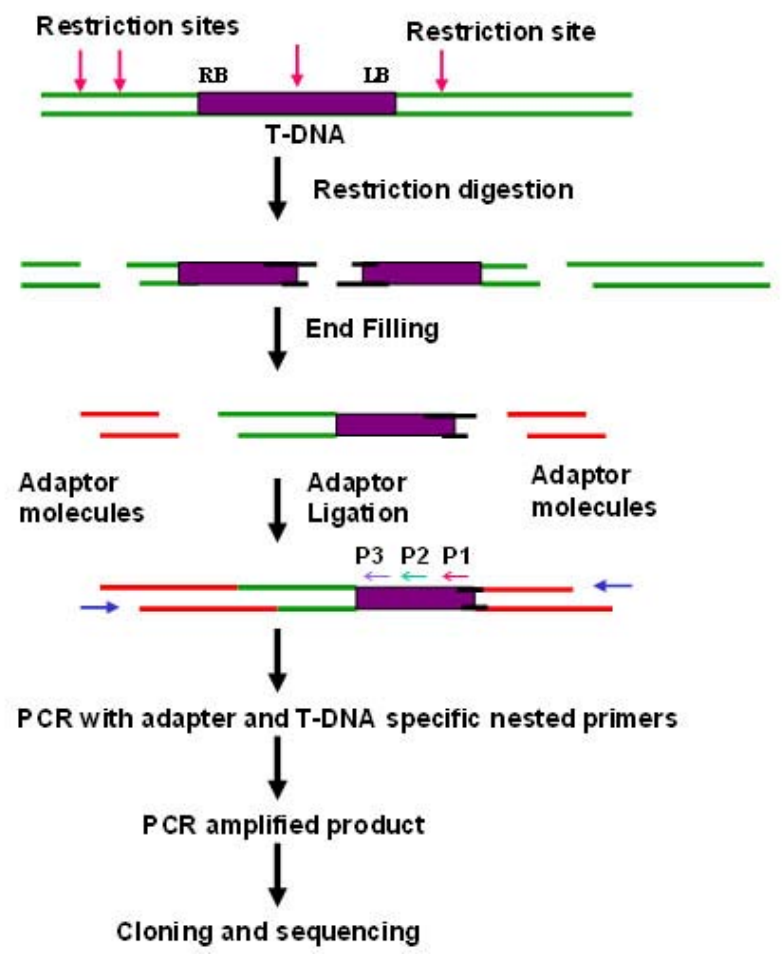

Figure 8. Schematic representation of adaptor PCR. Specific adaptor molecules are ligated to the ends of the restricted DNA fragments carrying part of the insert. The restricted fragments are end filled and subjected to PCR using primers specific to the adaptor region and nested primers specific to T-DNA. The flanking plant DNA region is represented by line (green). The adaptor molecules are shown in red. The adaptor specific primer is shown in blue arrow. The T-DNA specific nested primers (P1, P2 and P3) are indicated by red, green and purple arrows, respectively. 
expression patterns, throughout the plant life. Activation tags containing enhancer elements provoke tissue specific up regulation of activation tagged genes which potentially reveals more about the function of the gene than constitutive over expression. In this way even redundant genes might display an over expression phenotype, if their product is limiting or a change in concentration of gene products creates an imbalance that is manifested as a phenotype. These phenotypes can either directly reveal gene function or provide a clue to the pathway in which the concerned gene is involved. Moreover it might be possible to study the function of essential genes that display lethal knockout phenotypes by using these special vectors. The promise of this technology as illustrated by the cloning and characterization of several genes in Arabidopsis and the world wide efforts in progress should enable coverage of this model genome in a few years to come. Interestingly, TDNA mutational approach is now being successfully modified to tag genes in a number of economically important plant species, rice (430 Mbp) (Hiroyuki et al. 1999; Chen et al. 2003; Kolesnik et al. 2004; Sha et al. 2004), tomato (953 Mb) (Meissner et al. 2000), Brassica napus (1182 Mbp) (Bade et al. 2003), Medicago truncatula ( $\sim 454$ to $526 \mathrm{Mbp}$ )(Trieu et al. 2000) and poplar (550 Mbp) (Groover et al. 2004) (550 Mbp). Thus T-DNA tagging in conjunction with other mutation based techniques like transposon insertion, TILLING etc., would not only continue to provide useful information in Arabidopsis but is likely to prove an efficient tool for functional genomics in other plants also.

\section{REFERENCES}

ABRAHAMS, S.; LEE, E.; WALKER, A.R.; TANNER, G.J.; LARKIN, P.J. and ASHTON, A.R. The Arabidopsis TDS4 gene encodes leucoanthocyanidin dioxygenase (LDOX) and is essential for proanthocyanidin synthesis and vacuole development. The Plant Journal, September 2003, vol. 35 , no. 5, p. 624-636.

AGI. The Arabidopsis Genome Initiative. Analysis of genome sequence of the flowering plant Arabidopsisthaliana. Nature, December 2000, vol. 408, no. 6814, p. 796-815.

ALONSO, J.M.; STEPANOVA, A.N.; LEISSE, T.J.; KIM, C.J.; CHEN, H.; SHINN, P.; STEVENSON, D.K.; ZIMMERMAN, J.; BARAJAS, P.; CHEUK, R.; GADRINAB, C.; HELLER, C.; JESKE, A.; KOESEMA, E.; MEYERS, C.C.; PARKER, H.; PREDNIS, L.; ANSARI, Y.; CHOY, N.; DEEN, H.; GERALT, M.; HAZARI, N.; HOM, E.; KARNES, M.; MULHOLLAND, C.; NDUBAKU, R.; SCHMIDT, I.; GUZMAN, P.; AGUILAR-HENONIN, L.; SCHMID, M.; WEIGEL, D.; CARTER, D.E.; MARCHAND, T.; RISSEEUW, E.; BROGDEN, D.; ZEKO, A.; CROSBY, W.L.; BERRY, C.C. and ECKER, J.R. Genome-wide insertional mutagenesis of Arabidopsis thaliana. Science, August 2003, vol. 301, no. 5633, p. 653-657.
ALVARADO, M.C.; ZSIGMOND, L.M.; KOVACS, I.; CSEPLO, A.; KONCZ, C. and SZABADOS, L.M. Gene trapping with firefly luciferase in Arabidopsis-Tagging of stress-responsive genes. Plant Physiology, January 2004, vol. 134 , no. 1, p. 18-27.

ANTAL, Z.; RASCLE, C.; FEYRE, M. and BRUEL, C. Single oligonucleotide nested PCR: a rapid method for the isolation of genes and their flanking regions from expressed sequence tags. Current Genetics, October 2004, vol. 46, no. 4, p. 240-246.

ASHRAFI, K.; CHANG, F.Y.; WATTS, J.L.; FRASER, A.G.; KAMATH, R.S.; AHRINGER, J. and Ruvkun, G. Genome-wide RNAi analysis of Caenorhabditis elegans fat regulatory genes. Nature, January 2003, vol. 16, no. 421 (6920), p. 268-272.

AZPIROZ-LEEHAN, R. and FELDMANN, K.A. T-DNA insertion mutagenesis in Arabidopsis: going back and forth. Trends in Genetics, April 1997, vol. 13, no. 4, p. 152-156.

BADE, J.; VAN GRINSVEN, E.; CUSTERS, J.; HOEKSTRA, S. and PONSTEIN, A. T-DNA tagging in Brassica napus as an efficient tool for the isolation of new promoters for selectable marker genes. Plant Molecular Biology, May 2003, vol. 52, no. 1, p. 53-68.

BAE, M.S.; CHO, E.J.; CHOI, E.Y. and PARK, O.K. Analysis of the Arabidopsis nuclear proteome and its response to cold stress. The Plant Journal, December 2003, vol. 36 , no. 5, p. 652-663.

BALTER, M. Plant Science: data in key papers cannot be reproduced. Science, March 1999, vol. 283, no. 5480, p. 1987-1989.

BALZERGUE, S.; DUBREUCQ, B.; CHAUVIN, S.; LECLAINCHE, I.; LE BOULAIRE, F.; DEROSE, R.; SAMSON, F.; BIAUDET, Y.; LECHARNY, A.; CRUAUD, C.; WEISSENBACH, J.; CABOCHE, M. and LEPINIEC, L. Improved PCR-walking for large scale isolation of plant T-DNA borders. Biotechniques, March 2001, vol. 30, no. 3, p. 496-504.

BARTHELS, N.; VAN DER LEE, F.M.; KLAP, J.; GODDIJN, O.J.; KARIMI, M.; PUZIO, P.; GRUNDLER, F.M.; OHL, S.A.; LINDSEY, K.; ROBERTSON, L.; ROBERTSON, W.M., VAN MONTAGU, M.; GHEYSEN, G. and SIJMONS, P.C. Regulatory sequences of Arabidopsis drive reporter gene expression in nematode feeding structures. Plant Cell, December 1997, vol. 9, no. 12, p. 2119-2134.

BECKER, J.D.; BOAVIDA, L.C.; CARNEIRO, J.; HAURY, M. and FEIJO, J.A. Transcriptional profiling of Arabidopsis tissues reveals the unique characteristics of the pollen transcriptome. Plant Physiology, October 2003, vol. 133, no. 2, p. 713-725. 
BONAVENTURE, G.; SALAS, J.J.; POLLARD, M.R. and OHLROGGE, J.B. Disruption of the FATB gene in Arabidopsis demonstrates an essential role of saturated fatty acids in plant growth. Plant Cell, April 2003, vol. 15, no. 4, p. 1020-1033.

BOREVITZ, J.O.; XIA, Y.; BLOUNT, J.; DIXON, R.A. and LAMB, C. Activation tagging identifies a conserved MYB regulator of phenylpropanoid biosynthesis. Plant Cell, December 2000, vol. 12, no. 12, p. 2383-2394.

BORNER, G.H.; LILLEY, K.S.; STEVENS, T.J. and DUPREE, P. Identification of glycosylphosphatidylinositolanchored proteins in Arabidopsis. A proteomic and genomic analysis. Plant Physiology, June 2003, vol. 132, no. 2 , p. $568-577$.

BOUCHE, N. and BOUCHEZ, D. Arabidopsis gene knockout: phenotypes wanted. Current Opinion in Plant Biology, April 2001, vol. 4, no. 2, p. 111-117.

BOUCHEZ, D. and HOFTE, H. Functional genomics in plants. Plant Physiology, November 1998, vol. 118, no. 3, p. $725-732$.

BOUTON, S.; LEBOEUF, E.; MOUILLE, G.; LEYDECKER, M.T.; TALBOTEC, J.; GRANIER, F.; LAHAYE, M.; HOFTE, H. and TRUONG, H.N. QUASIMODO1 encodes a putative membrane-bound glycosyltransferase required for normal pectin synthesis and cell adhesion in Arabidopsis. Plant Cell, October 2002, vol. 14, no. 10, p. 2577-2590.

BUNDOCK, P. and HOOYKAAS, P. Severe developmental defects, hypersensitivity to DNA-damaging agents, and lengthened telomeres in Arabidopsis MRE11 mutants. Plant Cell, October 2002, vol. 14, no. 10, p. 24512462.

BIRNBAUM, K.; SHASHA, D.E.; WANG, J.Y.; JUNG, J.W.; LAMBERT, G.M.; GALBRAITH, D.W. and BENFEY, P.N. A gene expression map of the Arabidopsis root. Science, December 2003, vol. 302 (5652), no. 12, p. 1956-1960.

BRUNAUD, V.; BALZERGUE, S.; DUBREUCQ, B.; AUBOURG, S.; SAMSON, F.; CHAUVIN, S.; BECHTOLD, N.; CRUAUD, C.; DEROSE, R.; PELLETIER, G.; LEPINIEC, L.; CABOCHE, M. and LECHARNY, A. T-DNA integration into the Arabidopsis genome depends on sequences of pre-insertion sites. $E M B O$ Reports, December 2002, vol. 3, no. 12, p. 1152-1157.

CAMPISI, L.; YI, Y.; HEILIG, E.; HERMAN, B.; CASSISTA, A.J.; ALLEN, D.W.; XIANG, H. and JACK, T. Generation of enhancer trap lines in Arabidopsis and characterization of expression patterns in the inflorescence. The Plant Journal, September 1999, vol. 17, no. 6, p, 699707.
CASSON, S.A.; CHILLEY, P.M.; TOPPING, J.F.; EVANS, I.M.; SOUTER, M.A. and LINDSEY, K. The POLARIS gene of Arabidopsis encodes a predicted peptide required for correct root growth and leaf vascular patterning. Plant Cell, August 2002, vol. 14, no. 8, p. 17051721.

CHEN, S.; JIN, W.; WANG, M.; ZHANG, F.; ZHOU, J.; JIA, Q.; WU, Y.; LIU, F. and WU, P. Distribution and characterization of over 1000 T-DNA tags in rice genome. The Plant Journal, October 2003, vol. 36, no.1, p. 105-113.

CHIVASA, S.; NDIMBA, B.K.; SIMON, W.J.; ROBERTSON, D.; YU, X.L.; KNOX, J.P.; BOLWELL, P. and SLABAS, A.R. Proteomic analysis of the Arabidopsis thaliana cell wall. Electrophoresis, June 2002, vol. 23, no. 11, p. 1754-1765.

CLOUGH, S.J. and BENT, A.F. Floral dip: a simplified method for Agrobacterium-mediated transformation of Arabidopsis thaliana. The Plant Journal, December 1998, vol. 16 , no. 6, p. 735-743.

COOKE, R.; RAYNAL, M.; LAUDIE, M.; GRELLET, F.; DELSENY, M.; MORRIS, P.C.; GUERRIER, D.; GIRAUDAT, J.; QUIGLEY, F.; CLABAULT, G.; LI, Y. F.; MACHE, R.; KRIVITZKY, M.; GY, I.J.; KREIS, M.; LECHARNY, A.; PARMENTIER, Y.; MARBACH, J.; FLECK, J.; CLEMENT, B.; PHILIPPS, G.; HERVE, C.; BARDET, C.; TREMOUSAYGUE, D. and HOFTE, H. Further progress towards a catalogue of all Arabidopsis genes: analysis of a set of 5000 non-redundant ESTs. The Plant Journal, January 1996, vol. 9, no. 1, p. 101-124.

CRITCHLEY, J.H.; ZEEMAN, S.C.; TAKAHA, T.; SMITH, A.M. and SMITH, S.M. A critical role for disproportionating enzyme in starch breakdown is revealed by a knock-out mutation in Arabidopsis. The Plant Journal, April 2001, vol. 26, no. 1, p. 89-100.

CUTLER, S.R.; EHRHARDT, D.W.; GRIFFITTS, J.S. and SOMERVILLE, C.R. Random GFP::cDNA fusions enable visualization of subcellular structures in cells of Arabidopsis at a high frequency. Proceedings of the National Academy of Science of the United States of America, March 2000, vol. 97, no. 7, p. 3718-3723.

DE BUCK, S.; JACOBS, A.; VAN MONTAGU, M. and DEPICKER, A. The DNA sequences of T-DNA junctions suggest that complex T-DNA loci are formed by a recombination process resembling T-DNA integration. The Plant Journal, November 1999, vol. 20, no. 3, p. 295-304.

DEGREVE, H.; NGUYEN, V.K.; DEBOECK, F.; THIATOONG, L.; KARIMI, M. and HERNALSTEENS, J.P. TDNA tagging of the translation initiation factor elF-4A1 of Arabidopsisthaliana. Plant Science, September 2001, vol. 161, no. 4, p. 685-693. 
DEVIC, M.; HECHT, V.; BERGER, C.; DELSENY, M. and GALLOIS, P. An assessment of promoter trapping as a tool to study plant zygotic embryogenesis. Les Comptes Rendus de l'Académie des Sciences, Sciences de la Vie, January 1995, vol. 318, no. 1, p. 121-128.

DIEVART, A.; DALAL, M.; TAX, F.E.; LACEY, A.D.; HUTTLY, A.; LI, J. and CLARK, S.E. CLAVATA1 dominant-negative alleles reveal functional overlap between multiple receptor kinases that regulate meristem and organ development. Plant Cell, May 2003, vol. 15, no. 5, p. 1198-1211.

EGELHOFER, V.; GOBOM, J.; SEITZ, H.; GIAVALISCO, P.; LEHRACH, H. and NORDHOFF, E. Protein identification by MALDI-TOF-MS peptide mapping: a new strategy. Analytical Chemistry, April 2002, vol. 15, no. 74 (8), p. 1760-1771.

ERRAMPALLI, D.; PATTON, D.; CASTLE, L.; MICKELSON, L.; HANSEN, K.; SCHNALL, J.; FELDMANN, K. and MEINKE, D. Embryonic lethal and T-DNA Insertional Mutagenesis in Arabidopsis. Plant Cell, February 1991, vol. 3, no. 2, p. 149-157.

FALBEL, T.G.; KOCH, L.M.; NADEAU, J.A.; SEGUISIMARRO, J.M.; SACK, F.D. and BEDNAREK, S.Y. SCD1 is required for cell cytokinesis and polarized cell expansion in Arabidopsis thaliana. Development, September 2003, vol. 130, no. 17, p. 4011-4024.

FARRAR, K.; EVANS, I.M.; TOPPING, J.F.; SOUTER, M.A.; NIELSEN, J.E. and LINDSEY, K. EXORDIUM--a gene expressed in proliferating cells and with a role in meristem function, identified by promoter trapping in Arabidopsis. The Plant Journal, January 2003, vol. 33, no. 1, p. 61-73.

FELDMANN, K.A. Methods in Arabidopsis Research. World Scientific Pub Co Inc, 1992. p. 496, ISBN 981-020904-5.

FELDMANN, K.A. T-DNA insertion mutagenesis in Arabidopsis mutational spectrum. The Plant Journal, July 1991, vol. 1, no. 1, p. 71-82.

FELDMANN, K.A. and MARKS, M.D. Agrobacteriummediated transformation of germinating seeds of Arabidopsisthaliana. Molecular and General Genetics, July 1987, vol. 208, no. 3, p. 1-9.

FERREIRA DA ROCHA, P.S.C.; TOPPING, J.F. and LINDSEY, K. Promoter trapping in Arabidopsisore T-DNA tag, three transcripts and two thiolase genes. Journal of Experimental Botany, 1996, vol. 47, (supple), no. 24, p. 28.

FOBERT, P.R.; LABBE, H.; COSMOPAULOS, J.; GOTTLOB MCHUGH, S.; QUELLET, J.; HATTORI, J.; SUNOHARA, G.; IYER, V.N. and MIKI, B.L. T-DNA tagging of a seed coat specific cryptic promoter in tobacco. The Plant Journal, October 1994, vol. 6, no. 4, p. 567-577.

FOSTER, E.; HATTORI, J.; LABBE, H.; UELLET J.; FOBERT, P.R.; JAMES, L.E.; IYER, V.N. and MIKI, B.L. A tobacco cryptic constitutive promoter tCUP revealed by T-DNA tagging. Plant Molecular Biology, September 1999,vol. 41, no. 1, p. 45-55.

FUKAO, Y.; HAYASHI, M. and NISHIMURA, M. Proteomic analysis of leaf peroxisomal proteins in greening cotyledons of Arabidopsis thaliana. Plant Cell Physiology, July 2002, vol. 43, no. 7, p. 689-696.

GALBIATI, M., MORENO, M.A., NADZAN, G., ZOURELIDOU M. and DELLAPORTA, S.L. Large-scale T-DNA mutagenesis in Arabidopsis for functional genomic analysis. Functional and Integrative Genomics, May 2000, vol. 1 , no. 1, p. 25-34.

GARCIA, V.; BRUCHET, H.; CAMESCASSE, D.; GRANIER, F.; BOUCHEZ, D. and TISSIER, A. AtATM is essential for meiosis and the somatic response to DNA damage in plants. Plant Cell, January 2003, vol. 15, no. 1, p. 119-132.

GILLILAND, L.U.; PAWLOSKI, L.C.; KANDASAMY, M.K. and MEAGHER R.B. Arabidopsis actin gene ACT7 plays an essential role in germination and root growth. The Plant Journal, January 2003, vol. 33, no. 2, p. 319-328.

GOLlDACK, D.; POPOVA, O.V. and DIETZ, K.J. Mutation of the matrix metalloproteinase At2-MMP inhibits growth and causes late flowering and early senescence in Arabidopsis. The Journal of Biological Chemistry, February 2002, vol. 15, no. 277 (7), p. 55415547.

GOUJON, T.; MINIC, Z.; EL, AMRANI. A.; LEROUXEL, O.; ALETTI, E.; LAPIERRE, C.; JOSELEAU, J.P. and JOUANIN, L. AtBXL1, a novel higher plant (Arabidopsis thaliana) putative beta-xylosidase gene, is involved in secondary cell wall metabolism and plant development. The Plant Journal, February 2003a, vol. 33, no. 4, p. 677-690.

GOUJON, T.; SIBOUT, R.; POLLET, B.; MABA, B.; NUSSAUME, L.; BECHTOLD, N.; LU, F.; RALPH, J.; MILA, I.; BARRIERE, Y.; LAPIERRE, C. and JOUANIN, L. A new Arabidopsis thaliana mutant deficient in the expression of O-methyltransferase impacts lignins and sinapoyl esters. Plant Molecular Biology, April 2003b, vol. 51, no. 6, p. 973-989.

GRANT, J.J.; CHINI, A.; BASU, D. and LOAKE, G.J. Targeted activation tagging of the Arabidopsis NBS-LRR gene, ADR1, conveys resistance to virulent pathogens. Molecular Plant-Microbe Interactions, August 2003, vol. 16, no. 8, p. 669-680.

GROOVER, A.; FONTANA, R. J.; DUPPER, G.; MA, C.; 
MARTIENSSEN, R.; STRAUSS, S. and Milan R. Gene and enhancer Trap tagging of vascular-expressed genes in -poplar trees. Plant Physiology, April 2004, vol. 134, no. 4, p. $1742-1751$.

HAGIO, M.; SAKURAI, I.; SATO, S.; KATO, T.; TABATA, S. and Wada, H. Phosphatidylglycerol is essential for the development of thylakoid membranes in Arabidopsis thaliana. Plant Cell Physiology, December 2002, vol. 43, no. 12, p. 1456-1464.

HARTUNG, F.; ANGELIS, K.J.; MEISTER, A.; SCHUBERT, I.; MELZER, M. and PUCHTA, H. An archaebacterial topoisomerase homolog not present in other eukaryotes is indispensable for cell proliferation of plants. Current Biology, October 2002, vol. 15, no. 12 (20), p. 1787-1791.

HARTWECK, L.M.; SCOTT, C.L. and OLSZEWSKI, N.E. Two O-linked N-acetylglucosamine transferase genes of Arabidopsis thaliana L. Heynh. have overlapping functions necessary for. gamete and seed development. Genetics, July 2002, vol. 161, no. 3, p. 1279-1291.

HENIKOFF, S.; TILL, B.J. and COMAI, L. TILLING. Traditional Mutagenesis Meets Functional Genomics. Plant Physiology, June 2004, vol. 135, p. 630-636.

HENRIQUE, R.; JASIK, J.; KLEIN, M.; MARTINOIA, E.; FELLER, U.; SCHELL, J.; PAIS, M.S. and KONCZ. C. Knock-out of Arabidopsis metal transporter gene IRT1 results in iron deficiency accompanied by cell differentiation defects. Plant Molecular Biology, November 2002, vol. 50, no. 4-5, p. 587-597.

HIROYUKI, E.; IZAWA, T.; KAWAHARA, M.; KOMATSU, M.; KOH, S.; KYOZUKA, J. and SHIMAMOTO, K. Ac as a tool for the functional genomics of rice. The Plant Journal, September 1999, vol. 19, no. 5, p. 605-613.

HOSY, E.; VAVASSEUR, A.; MOULINE, K.; DREYER, I.; GAYMARD, F.; POREE, F.; BOUCHEREZ, J.; LEBAUDY, A.; BOUCHEZ, D.; VERY, A.A.; SIMONNEAU, T.; THIBAUD, J.B. and SENTENAC, H. The Arabidopsis outward K+ channel GORK is involved in regulation of stomatal movements and plant transpiration. Proceedings of the National Academy of Science of the United States of America, April 2003, vol. 100, no. 9, p. 5549-5554.

HUANG, S.; GERNY, R.E.; BHAT, D.S. and BROWN, S.M. Cloning of an Arabidopsis patatin-like gene, STURDY, by activation T-DNA tagging. Plant Physiology, February 2001, vol. 125, no. 2, p. 573-584.

HUQ, E.; TEPPERMAN, J.M. and QUAIL, P.H. GIGANTEA is a nuclear protein involved in phytochrome signaling in Arabidopsis. Proceedings of the National
Academy of Science of the United States of America, August 2000,vol. 97, no. 17, p. 9789-9794.

IGARASHI, D.; MIWA, T.; SEKI, M.; KOBAYASHI, M.; KATO, T.; TABATA, S.; SHINOZAKI, K. and OHSUMI, C. Identification of photorespiratory glutamate:glyoxylate minotransferase (GGAT) gene in Arabidopsis. The Plant Journal, March 2003, vol. 33, no. 6, p. 975-987.

ISHIKAWA, A.; TANAKA, H.; NAKAI, M. and ASAHI, T. Deletion of a chaperonin 60 beta gene leads to cell death in the Arabidopsis lesion initiation 1 mutant. Plant Cell Physiology, March 2003, vol. 44, no. 3, p. 255-261.

ITO, T. and MEYEROWITZ, E. M. Over expression of a gene encoding a cytochrome P450, CYP78A9, induces large and seedless fruit in Arabidopsis. Plant Cell, September 2000, vol. 12, no. 9, p. 1541-1550.

JAVOT, H.; LAUVERGEAT, V.; SANTONI, V.; MARTIN-LAURENT, F.; GUCLU, J.; VINH, J.; HEYES, J.; FRANCK, K.I.; SCHAFFNER, A.R.; BOUCHEZ, D. and MAUREL, C. Role of a single aquaporin isoform in root water uptake. Plant Cell, February 2003, vol. 15, no. 2, p. 509-522.

JEFFERSON, R.A.; KARANAGH, T.A. and BEVAN, M.W. GUS fusion: b- Glucuronidase as a sensitive and versatile gene fusion marker in higher plants. The EMBO Journal, December 1987, vol. 6, no. 13, p. 3901-3907.

JEONG, D.H.; AN, S.; KANG, H.G.; MOON, S.; HAN, J.J.; PARK, S.; LEE, H.S.; AN, K. and AN, G. T-DNA insertional Mutagenesis for activation tagging in rice. Plant Physiology, December 2002, vol. 130, no. 4, p. 1636-1644.

JOHANNESSON, H.; WANG, Y.; HANSON, J. and ENGSTROM, P. The Arabidopsis thaliana homeobox gene ATHB5 is a potential regulator of abscisic acid responsiveness in developing seedlings. Plant Molecular Biology, March 2003, vol. 51, no. 5, p. 719-729.

JONES, P.; MESSNER, B.; NAKAJIMA, J.; SCHAFFNER, A.R. and SAITO, K. UGT73C6 and UGT78D1, glycosyltransferases involved in flavonol glycoside biosynthesis in Arabidopsis thaliana. The Journal of Biological Chemistry, November 2003, vol. 7, no. 278 (45), p. 43910-43918.

JORGENSEN, R.; SNYDER, C. and JONES, J.G. T-DNA is organized predominantly in inverted repeat structures in plants transformed with Agrobacterium tumefaciens C58 derivatives. Molecular and General Genetics, April 1987, vol. 207, no. 3, p. 471-477.

KAISER, B.N.; RAWAT, S.R.; SIDDIQI, M.Y.; MASLE, J. and GLASS, A.D. Functional analysis of an Arabidopsis T-DNA "knockout" of the high-affinity $\mathrm{NH}^{+}$transporter AtAMT1;1. Plant Physiology, November 2002, vol. 130, no. 3 , p. $1263-1275$. 
KAKIMOTO, T. CKI1, a histidine kinase homolog implicated in cytokinin signal transduction. Science, November 1996, vol. 274 (5289), no. 8, p. 982-985.

KAMATH, R.S. and AHRINGER, J. Genome-wide RNAi screening in Caenorhabditis elegans. Methods, August 2003, vol. 30, no. 4, p. 313-321.

KARDAILSKY, I.; SHUKLA, V.K.; AHN, J.H.; DAGENAIS, N.; CHRISTENSEN, S.K.; NGUYEN, J.T.; CHORY, J.; HARRISON, M.J. and WEIGEL, D. Activation tagging of the floral inducer FT. Science, December 1999,vol. 286 (5446), no. 3, p. 1962-1965.

KAWAMURA, Y. and UEMURA, M. Mass spectrometric approach for identifying putative plasma membrane proteins of Arabidopsis leaves associated with cold acclimation. The Plant Journal, October 2003, vol. 36, no. 2, p. 141-154.

KIEGLE, E.; MOORE, C.A.; HASELOFF, J.; TESTER, M.A. and KNIGHT, M.R. Cell-type-specific calcium responses to drought, salt and cold in the Arabidopsis root. The Plant Journal, July 2000, vol. 23, no. 2, p. 267-278.

KERTBUNDIT, S.; DE GREVE, H.; DEBOECK, F.; VAN MONTAGU, M. and HERNALSTEENS, J.P. In vivo random $\beta$-glucuronidase gene fusions in Arabidopsis thaliana. Proceedings of the National Academy of Science of the United States of America, June 1991, vol. 88, no. 12, p. 5212-5216.

KERSTETTER, R.A, BOLLMAN, K.; TAYLOR, R.A.; BOMBLIES, K. and POETHIG, R.S. KANADI regulates organ polarity in Arabidopsis. Nature, June 2001, vol. 411, no. 6838 , p. $706-709$.

KIBA, T.; YAMADA, H.; SATO, S.; KATO, T.; TABATA, S.; YAMASHINO, T. and MIZUNO, T. The type-A response regulator, ARR15, acts as a negative regulator in the cytokinin-mediated signal transduction in Arabidopsis thaliana. Plant Cell Physiology, August 2003, vol. 44, no. 8, p. 868-874.

KMIECIAK, M.; SIMPSON, C.G.; LEWANDOWSKA, D.; BROWN, J.W. and JARMOLOWSKI, A. Cloning and characterization of two subunits of Arabidopsis thaliana nuclear cap-binding complex. Gene, January 2002, vol. 23, no. 283 (1-2), p. 171-183.

KOIWA, H.; BARB, A.W.; XIONG, L.; LI, F.; MCCULLY, M.G.; LEE, B.H.; SOKOLCHIK, I.; ZHU, J.; GONG, Z.; REDDY, M.; SHARKHUU, A.; MANABE, Y.; YOKOI, S.; ZHU, J.K.; BRESSAN, R.A. and HASEGAWA, P.M. C-terminal domain phosphatase-like family members (AtCPLs) differentially regulate Arabidopsis thaliana abiotic stress signaling, growth, and development. Proceedings of the National Academy of Science of the United States of America, August 2002, vol. 99, no. 16, p. 10893-10898.
KOLESNIK, T.; SZEVERENYI, I.; BACHMANN, D.; KUMAR, C.S.; JIANG, S.; RAMAMOORTHY, R.; CAI, M.; MA, Z.G.; SUNDARESAN, V. and RAMACHANDRAN, S. Establishing an efficient Ac/Ds tagging system in rice: large-scale analysis of Ds flanking sequences. The Plant Journal, January 2004, vol. 37, no. 2, p. 301-314.

KOMORI, T.; OHTA, S.; MURAI, N.; TAKAKURA, Y.; KURAYA, Y.; SUZUKI, S.; HIEI, Y.; IMASEKI, H. and NITTA, N. Map-based cloning of a fertility restorer gene, Rf-1, in rice (Oryza sativa L.). The Plant Journal, February 2004, vol. 37, no. 3, p. 315-325.

KONCZ, C.; MARTINI, N.; MAYERHOFER, R.; KONCZ-KALMAN, Z., KORBER, H.; REDEI, G.P. and SCHELL, J. High frequency T-DNA- mediated gene tagging in plants. Proceedings of the National Academy of Science of the United States of America, November 1989, vol. 86 , no. 21 , p. $8467-8471$.

KONONOV, M.E.; BASSUNER, B. and GELVIN, S.B. Integration of T-DNA binary vector 'backbone' sequences into the tobacco genome: evidence for multiple complex patterns of integration. The Plant Journal, May 1997, vol. 11 , no. 5, p. 945-957.

KRYSAN, P.J.; YOUNG, J.C. and SUSSMAN, M.R. TDNA as an insertional mutagen in Arabidopsis. Plant Cell, December 1999,vol. 11, no.12, p. 2283-2290.

KWAK, J.M.; MOON, J.H.; MURATA, Y.; KUCHITSU, K.; LEONHARDT, N.; DELONG, A. and SCHROEDER, J.I. Disruption of a guard cell-expressed protein phosphatase $2 \mathrm{~A}$ regulatory subunit, $\mathrm{RCN} 1$, confers abscisic acid insensitivity in Arabidopsis. Plant Cell, November 2002, vol. 14, no. 11, p. 2849-2861.

LECLERE, S. and BARTEL, B. A library of Arabidopsis 35S-cDNA lines for identifying novel mutants. Plant Molecular Biology, August 2001, vol. 46, no. 6, p. 695-703.

LEE, S.H.; KIM, J.Y.; KIM, S.H.; KIM, S.J.; LEE, K.; HAN S.K.; CHOI, H.S.; JEONG, D.H.; AN, G. and KIM, S.R.Trapping and characterization of cold-responsive genes from T-DNA tagging lines in rice. Plant Science, January 2004, vol. 166, no. 1, p. 69-79.

LEE, H.; SUH, S.S.; PARK, E.; CHO, E.; AHN, J.H.; KIM, S.G.; LEE, J.S.; KWON, Y.M. and LEE, I. The AGAMOUS-LIKE 20 MADS domain protein integrates floral inductive pathways in Arabidopsis. Genes and Development, September 2000, vol. 15; no. 14 (18), p. 2366-2376.

LI, J.; LEASE, K.A.; TAX, F.E. and WALKER, J.C. BRS1, a serine carboxypeptidase, regulates BRI1 signaling in Arabidopsis thaliana. Proceedings of the National Academy of Science of the United States of America, May 2001, vol. 98, no. 10, p. 5916-5921. 
LI, S.; BLANCHOIN, L.; YANG, Z. and LORD, E.M. The putative Arabidopsis arp2/3 complex controls leaf cell morphogenesis. Plant Physiology, August 2003, vol. 132, no. 4, p. 2034-2044.

LIN, X.; KAUL, S.; ROUNSLEY, S.; SHEA, T.P.; BENITO, M.I.; TOWN, C.D.; JUFII, C.Y.; MASON, T.; BOWMAN, C.L. and BARNSTEAD, M. Sequence analysis of chromosome 2 of the plant Arabidopsisthaliana. Nature, December 1999, vol.402, no. 6763, p. 761-768.

LINDSEY, K.; WEI, W.; CLARKE, M.C.; MCARDLE, H.F.; ROOKE, L.M. and TOPPING, J.F. Tagging genomic sequences that direct transfer expression by activation of a promoter trap in plants. Transgenic Research, January 1993, vol. 2, no. 1, p. 33-47.

LIU, Z.; HONG, S.W.; ESCOBAR, M.; VIERLING, E.; MITCHELL, D.L.; MOUNT, D.W. and HALL, J.D. Arabidopsis UVH6, a homolog of human XPD and yeast RAD3 DNA repair genes, functions in DNA repair and is essential for plant growth. Plant Physiology, July 2003, vol. 132 , no. 3, p. 1405-1414.

LIU, Y.; MITSUKAWA, N.; OOSUMI, T. and WHITTIER, R. Efficient isolation and mapping of Arabidopsisthaliana T-DNA insert junctions by thermal asymmetric interlaced PCR. The Plant Journal, September 1995,vol. 8, no. 3, p. 457-463.

MAES, T.; KEUKELEIRE, P.D. and GERATS, T. Plant tagnology. Trends in Plant Scence, March1999, vol. 4, no. 3, p. $90-96$.

MANDAL, A.; SANDGEN, M.; HOLMSTROM, K.O.; GALLOIS, P. and PALUA, E.T. Identification of Arabidopsisthaliana sequences responsive to low temperature and abscisic acid by T-DNA tagging and in vivo gene fusion. Plant Molecular Biology Reporter, 1995, vol. 13 , no. 3, p. 243-254.

MARKS, M.D. and FELDMANN, K.A. Trichome development in Arabidopsis thaliana I.T-DNA tagging of the GLABROUS1 gene. Plant Cell, November 1989, vol. 1, no. 11, p. 1043-1050.

MALDONADO, A.M.; DOERNER, P.; DIXON, R.A.; LAMB, C.J. and CAMERON, R.K. A putative lipid transfer protein involved in systemic resistance signalling in Arabidopsis. Nature, September 2002, vol. 26, no. 419 (6905), p. 399-403.

MARTIENSSEN, R.A. Functional genomics: probing plant gene function and expression with transposons. Proceedings of the National Academy of Science of the United States of America, March 1998, vol. 95, no. 5, p. 2021-2026.

MASCLAUX, F.; CHARPENTEAU, M.; TAKAHASHI, T.; PONT-LEZICA, R. and GALAUD, J.P. Gene silencing using a heat-inducible RNAi system in Arabidopsis. Biochemistry and Biophysics Research Communications, August 2004, vol. 20, no. 321 (2), p. 364-369.

MATZKE, M.A. and MATZKE, A.J. M. How and why do plants inactivate homologues (trans)genes? Plant Physiology, March 1995, vol. 107, no. 3, p. 679-685.

MATHEWS, H.; CLENDENNEN, S.K.; CALDWELL, C.G.; LIU, X.L.; CONNORS, K.; MATHEIS, N.; SCHUSTER, D.K.; MENASCO, D.J.; WAGONER, W.; LIGHTNER, J. and WAGNER, D.R. Activation tagging in tomato identifies a transcriptional regulator of anthocyanin biosynthesis, modification, and transport. Plant Cell, August 2003, vol. 15, no. 8, p. 1689-1703.

MCCALLUM, C.M.; COMAI, L.; GREENE, E.A. and HENIKOFF, S. Targeted screening for induced mutations. Nature Biotechnology, April 2000a, vol. 18, no. 4, p. 455457.

MCCALLUM, C.M.; COMAI, L.; GREENE, E.A. and HENIKOFF, S Targeting induced local lesions in genomes (TILLING) for plant functional genomics. Plant Physiology, June 2000b, vol. 123, no. 2, p. 439-442.

MEIERHOFF, K.; FELDER, S.; NAKAMURA, T.; BECHTOLD, N. and SCHUSTER, G. HCF152, an Arabidopsis RNA binding pentatricopeptide repeat protein involved in the processing of chloroplast psbB-psbT-psbHpetB-petD RNAs. Plant Cell, June 2003, vol. 15, no. 6, p. 1480-1495.

MEISSNER, R.; CHAGUE, V.; ZHU, Q.; EMMANUEL, E.; ELKIND, Y. and LEVY, A.A. Technical advance: a high throughput system for transposon tagging and promoter trapping in tomato. The Plant Journal, May 2000, vol. 22, no. 3, p. 265-274.

MEISSNER, R.C.; JIN, H.; COMINELLI, E.; DENEKAMP, M.; FUERTES, A.; GRECO, R.; KRANZ, H. D.; PENFIELD, S.; PETRONI, K.; URZAINQUI, A.; MARTIN, C.; PAZ-ARES, J.; SMEEKENS, S.; TONELLI, C.; WEISSHAAR, B.; BAUMANN, E.; KLIMYUK, V.; MARILLONNET, S.; PATEL, K.; SPEULMAN, E.; TISSIER, A.F.; BOUCHEZ, D.; JONES, J.J.; PEREIRA, A. and WISMAN, E. Function search in a large transcription factor gene family in Arabidopsis: assessing the potential of reverse genetics to identify insertional mutations in R2R3 MYB genes. Plant Cell, October 1999, vol. 11, no. 10, p. 1827-1840.

MEISSNER, R.; JACOBSON, Y.; MELAMED, S.; LEVYATUV, S.; SHALEV, G.; ASHRI, A.; ELKIND, Y. and LEVY, A.A. A new model system for tomato genetics. The Plant Journal, December 1997, vol. 12, no. 6, p. 14651472 .

MOLLIER, P.; HOFFMAN, B.; ORSEL, M. and PELLETIER, G. Tagging of a cryptic promoter that confers 
root-specific gus expression in Arabidopsisthaliana. Plant Cell Report, November 2000, vol. 19, no. 11, p. 1076-1083.

MOLLIER, P.; MONTORO, P.; DELARUE, M.; BECHTOLD, N.; BELLINI, C. and PELLETIER, G. Promoter less gusA expression in a large number of Arabidopsis thaliana transformants obtained by in planta infiltration method. Les Comptes Rendus de l'Académie des Sciences, Sciences de la Vie, 1995, vol. 318, no. 6, p. 465474.

MUSKETT, P.R. and LINDSEY, K. Identification and isolation of a vascular tissue-expressed gene required for root development in Arabidopsisthaliana by promoter trapping. Journal of Experimental Botany, 1995, vol. 49, no. 39 , (supple), p. 6.57.

NAKAZAWA, M.; YABE, N.; ICHIKAWA, T.; YAMAMOTO, Y.Y.; YOSHIZUMI, T.; HASUNUMA, K. and MATSUI, M. DFL1, an auxin-responsive GH3 gene homologue, negatively regulates shoot cell elongation and lateral root formation, and positively regulates the light response of hypocotyl length. The Plant Journal, January 2001, vol. 25, no. 2, p. 213-221.

OHNO, C.K.; REDDY, G.V.; HEISLER, M.G. and MEYEROWITZ, E.M. The Arabidopsis JAGGED gene encodes a zinc finger protein that promotes leaf tissue development. Development, March 2004, vol. 131, no. 5, p. 1111-1122.

OSTERGAARD, L. and YANOFSKY, M.F. Establishing gene function by mutagenesis in Arabidopsis thaliana. The Plant Journal, September 2004, vol. 39, no. 5, p. 682-696.

PARINOV, S.; SEVUGAN, M.; DE, Y.; YANG, W.C.; KUMARAN, M. and SUNDARESAN, V. Analysis of flanking sequences from dissociation insertion lines: A database for reverse genetics in Arabidopsis. Plant Cell, December 1999, vol. 11, no. 12, p. 2263-2270.

PARK, D.H.; LIM, P.O.; KIM, J.S.; CHO, D.S.; HONG, S.H. and NAM, H.G. The Arabidopsis COG1 gene encodes a Dof domain transcription factor and negatively regulates phytochrome signaling. The Plant Journal, April 2003, vol. 34 , no. 2, p. 161-171.

PERRIN, R.M.; JIA, Z.; WAGNER, T.A.; O'NEILL, M.A.; SARRIA, R.; YORK, W.S.; RAIKHEL, N.V. and KEEGSTRA, K. Analysis of xyloglucan fucosylation in Arabidopsis. Plant Physiology, June 2003, vol. 132, no. 2, p. $768-778$.

PERRY, J.A.; WANG, T.L.; WELHAM, T.J.; GARDNER, S.; PIKE, J.M.; YOSHIDA, S. and PARNISKE, M. A TILLING reverse genetics tool and a web-accessible collection of mutants of the legume Lotus japonicus. Plant Physiology, March 2003, vol. 131, p. 866-871.

PISCHKE, M.S.; JONES, L.G.; OTSUGA, D.;
FERNANDEZ, D.E.; DREWS, G.N. and SUSSMAN, M.R. An Arabidopsis histidine kinase is essential for megagametogenesis. Proceedings of the National Academy of Science of the United States of America, November 2002, vol. 94, no. 24, p. 15800-15805.

PLESCH, G.; KAMANN, E.; and MUELLER, R.B. Cloning of regulatory sequences mediating guard-cellspecific gene expression. Gene, May 2000, vol. 249, no. 1, p. 83-89.

PUZIO, P.S.; LAUSEN, A.; ENGLER, J.; CAL, D.; GHEYSEN, G. and GRUNDLER, F. M.W. Isolation of a gene from Arabidopsis thaliana related to nematode feeding structures. Gene, October 1999, vol. 239, no. 1, p. 163-172.

QIN, G.; KANG, D.; DONG, Y.; SHEN, Y.; ZHANG, L.; DENG, X.; ZHANG, Y.; LI, S.; CHEN, N.; NIU, W.; CHEN, C.; LIU, P.; CHEN, H.; LI, J.; REN, Y.; GU, H.; DENG, X.W.; QU, L.J. and CHEN, Z. Obtaining and analysis of flanking sequences from T-DNA transformants of Arabidopsis. Plant Science, May 2003, vol. 165, no. 5, p. 941-949.

RATCLIFFE, O.J.; KUMIMOTO, R.W.; WONG, B.J. and RIECHMANN, J.L. Analysis of the Arabidopsis MADS AFFECTING FLOWERING gene family: MAF2 prevents vernalisation by short periods of cold. Plant Cell, May 2003 , vol. 15 , no. 5 , p. 1159-1169.

RESMINATH, R.; PRASAD, A.M.; THAKARE, D.R.; SIVANANDAN, C.; BHAT, S.R. and SRINIVASAN, R. Promoter trapping in Arabidopsis using T-DNA insertional mutagenesis, Journal of Plant Biochemistry and Biotechnology, January 2005, vol. 14, no. 1, p.1-8.

ROSSO, M. G.; LI, Y.; STRIZHOV, N.; REISS, B.; DEKKER, K. and WEISSHAAR, B. An Arabidopsis thaliana T-DNA mutagenized population (GABI-Kat) for flanking sequence tag-based reverse genetics. Plant Molecular Biology, September 2003, vol. 53, no. 1-2, p. 247-259.

SAMSON, F.; BRUNAUD, V.; BALAERGUE, S.; DUBREUCQ, B.; LEPINIEC, L.; PELLETIER, G.; CABOCHE, M. and LECHARNY, A. FLAGdb/FST: a database of mapped flanking insertion sites (FSTs) of Arabidopsis thaliana T-DNA transformants. Nucleic Acid Research, January 2002, vol. 30, no. 1, p. 94-97.

SCHNURR, J.A.; SHOCKEY, J.M.; DE BOER, G.J. and BROWSE, J.A. Fatty acid export from the chloroplast. Molecular characterization of a major plastidial acylcoenzyme A synthetase from Arabidopsis. Plant Physiology, August 2002, vol. 129, no. 4, p. 1700-1709.

SCHOMBURG, F.M.; BIZZELL, C.M.; LEE, D.J.; ZEEVAART, J.A. and AMASINO, R.M. Over expression of a novel class of gibberellin 2-oxidases decreases 
gibberellin levels and creates dwarf plants. Plant Cell, January 2003, vol. 15, no. 1, p. 151-163.

SCHUMANN, U.; WANNER, G.; VEENHUIS, M.; SCHMID, M. and GIETL, C. AthPEX10, a nuclear gene essential for peroxisome and storage organelle formation during Arabidopsis embryogenesis. Proceedings of the National Academy of Science of the United States of America, August 2003, vol. 100, no. 16, p. 9626-9631.

SESSIONS, A.; BURKE, E.; PRESTING, G.; AUX, G.; MCELVER, J.; PATTON, D.; DIETRICH, B.; HO, P.; BACWADEN, J.; KO, C.; CLARKE, J.D.; COTTON, D.; BULLIS, D.; SNELL, J.; MIGUEL, T.; HUTCHISON, D.; KIMMERLY, B.; MITZEL, T.; KATAGIRI, F.; GLAZEBROOK, J.; LAW, M. and GOFF, S.A. A highthroughput Arabidopsis reverse genetics system. Plant Cell, December 2002, vol. 14, no. 12, p. 2985-2994.

SHA, Y.; LI, S.; PEI, Z.; LUO, L.; TIAN, Y. and HE, C. Generation and flanking sequence analysis of a rice T-DNA tagged population. Theoretical and Applied Genetics, January 2004, vol. 108, no. 2, p. 306-314.

SIDDIQUI, N.U.; STRONGHILL, P.E.; DENGLER, R.E.; HASENKAMPF, C.A. and RIGGS, C.D. Mutations in Arabidopsis condensin genes disrupt embryogenesis, meristem organization and segregation of homologous chromosomes during meiosis. Development, July 2003, vol. 130, no. 14, p. 3283-3295.

SILVA, H.; YOSHIOKA, K.; DOONER, H.K. and KLESSIG, D.F. Characterization of a new Arabidopsis mutant exhibiting enhanced disease resistance. Molecular Plant Microbe Interaction, December 1999, vol. 12, no. 12, p. 1053-1063.

SINGH-GASSON, S.; GREEN, R.D.; YUE, Y.; NELSON, C.; BLATTER, F.; SUSSMAN, M.R. and CERRINA, F. Maskless fabrication of light-directed oligonucleotide microarrays using a digital micro mirror array. Nature Biotechnology, October 1999, vol. 17, no. 10, p. 974-978.

SOMERVILLE, C. and SOMERVILLE, S. Plant functional genomics. Science, July 1999, vol. 285 (5426), no. 16, p. 380-383.

SORENSEN, A.M.; KROBER, S.; UNTE, U.S.; HUIJSER, P.; DEKKER, K. and SAEDLER, H. The Arabidopsis Aborted Microspores (AMS) gene encodes a MYC class transcription factor. The Plant Journal, January 2003, vol. 33 , no. 2, p. 413-423.

SPEULMAN, E.; METZ, P.L.J.; VAN ARKEL, G.; HEKKERT, B.T.L.; STIEKEMA, W.J. and PEREIRA, A. A two-component enhancer-inhibitor transposon mutagenesis system for the functional analysis of the Arabidopsis genome. Plant Cell, October 1999, vol. 11, no. 10, p. 1853-1866.
STACEY, M.G.; KOH, S.; BECKER, J.; and STACEY, G. AtOPT3, a member of the oligopeptide transporter family, is essential for embryo development in Arabidopsis. Plant Cell, November 2002, vol. 14, no. 11, p. 2799-2811.

STACHEL, S.E.; TIMMERMAN, B. and ZAMBRYSKI, P. Activation of Agrobacterium tumefaciens vir gene expression generates multiple single-stranded T-strand molecules from the pTiA6 T-region: requirement for $5^{\prime}$ vir D gene products. The EMBO Journal, April 1987, vol. 6, no. 4 , p. $857-863$.

STEINEBRUNNER, I.; WU, J.; SUN, Y.; CORBETT, A. and ROUX, S.J. Disruption of apyrases inhibits pollen germination in Arabidopsis. Plant Physiology, April 2003, vol. 131, no. 4, p. 1638-1647.

SUESSLIN, C. and FROHNMEYER, H. An Arabidopsis mutant defective in UV-B light-mediated responses. The Plant Journal, February 2003, vol. 33, no. 3, p. 591-601.

SUN, X.; CAO, Y.; YANG, Z.; XU, C.; LI, X.; WANG, S. and ZHANG, Q. Xa26, a gene conferring resistance to Xanthomonas oryzae pv. oryzae in rice encodes an LRR receptor kinase-like protein. The Plant Journal, February 2004, vol. 37 , no. 4, p. 517-527.

SUN, J.; NIU, Q.W.; TARKOWSKI, P.; ZHENG, B.; TARKOWSKA, D.; SANDBERG, G.; CHUA, N.H. and ZUO, J. The Arabidopsis AtIPT8/PGA22 gene encodes an isopentenyl transferase that is involved in de novo cytokinin biosynthesis. Plant Physiology, January 2003, vol. 131, no. 1, p. 167-176.

SUNDARESAN, V.; SPRINGER, P.; VOLPE, T.; HAWARD, S.; JONES, J.D.G.; DEAN, C.; MA, H. and MARTIENSSEN, R. Patterns of gene action in plant development revealed by enhanced trap and gene trap transposable elements. Genes and Development, July 1995, vol.9, no. 14, p. 1797-1810.

SUSSMAN, M.R.; AMASINO, R.M.; YOUNG, J.C.; KRYSAN, .PJ. and AUSTIN-PHILLIPS, S. The Arabidopsis knockout facility at the University of Wisconsin-Madison. Plant Physiology, December 2000, vol. 124 , no. 4, p. 1465-1467.

SZABADOS, L.; KOVACS, I.; OBERSCHALL, A.; ABRAHAM, E.; KEREKES, I.; ZSIGMOND, L.; NAGY, R.; ALVARADO, M.; KRASOVSKAJA, I.; GAL, M.; BERENTE, A.; REDEI, G.P.; HAIM, A.B. and KONCZ, C. Distribution of 1000 sequenced T-DNA tags in the Arabidopsis genome. The Plant Journal, October 2002, vol. 32 , no. 2, p. 233-242.

TAGMOUNT, A.; BERKEN, A. and TERRY, N. An essential role of s-adenosyl-L-methionine: L-methionine smethyltransferase in selenium volatilization by plants. Methylation of selenomethionine to selenium-methyl-Lselenium- methionine, the precursor of volatile selenium. 
Plant Physiology, October 2002, vol. 130, no. 2, p. 847856.

TANIGUCHI, M.; TANIGUCHI, Y.; KAWASAKI, M.; TAKEDA, S.; KATO, T.; SATO, S.; TABATA, S.; MIYAKE, $\mathrm{H}$. and SUGIYAMA, $\mathrm{T}$. Identifying and characterizing plastidic 2-oxoglutarate/malate and dicarboxylate transporters in Arabidopsis thaliana. Plant Cell Physiology, July 2002, vol. 43, no. 7, p. 706-717.

TAX, F.E. and VERNON D.M. T-DNA-associated duplication/translocations in Arabidopsis implications for mutant analysis and functional genomics. Plant Physiology, August 2001, vol. 126, no. 4, p. 1527-1538.

TEIGE, M.; SCHEIKL, E.; EULGEM, T.; DOCZI, R.; ICHIMURA, K.; SHINOZAKI, K.; DANGL, J.L. and HIRT, H. The MKK2 pathway mediates cold and salt stress signalling in Arabidopsis. Molecular Cell, July 2004, vol. 2, no. 15 (1), p. 141-152.

TERADA, R.; URAWA, H.; INAGAKI, Y.; TSUGANE, $\mathrm{K}$. and IIDA, S. Efficient gene targeting by homologous recombination in rice. Nature Biotechnology, November 2002, vol. 20, no. 11, p. 1030-1034.

TIAN, L.; MAGALLANES-LUNDBACK, M.; MUSETTI, V. and DELLAPENNA, D. Functional analysis of beta- and epsilon-ring carotenoid hydroxylases in Arabidopsis. Plant Cell, June 2003, vol. 15, no. 6, p. 1320-1332.

TILL, B.J.; REYNOLDS, S.H.; GREENE, E.A.; CODOMO, C.A.; ENNS, L.C.; JOHNSON, J.E.; BURTNER, C.; ODDEN, A.R.; YOUNG, K.; TAYLOR, N.; HENIKOFF J.G.; COMAI, L. and HENIKOFF, S. Large-scale discovery of induced point mutations with high-throughput TILLING. Genome Research, March 2003, vol. 13, no. 3, p. 524-530.

TISSIER, A.F.; MARILLONNET, S.; KLIMYUK, V.; PATEL, K.; TORRES, M.A.; MURPHY, G. and JONES, J.D.G. Multiple independent defective Suppressor-Mutator transposon insertions in Arabidopsis: a tool for functional genomics. Plant Cell, October 1999, vol. 1, no. 10, p. 18411852.

TOPPING, J.F. and LINDSEY, K. Promoter trap markers differentiate structural and positional components of polar development in Arabidopsis. Plant Cell, October 1997, vol. 9, no. 10, p. 1713-1725.

TOPPING, J.F.; AGYEMAN, F.; HENRICOT, B. and LINDSEY, K. Functional tagging of regulatory elements in the plant genome. Development, August 1994, vol. 112, no. 4, p. 1009-1019.

TRIEU, A.T.; BURLEIGH, S.H.; KARDAILSKY, I.V.; MALDONADO-MENDOZA, I.E.; VERSAW, W.K.; BLAYLOCK, L.A.; SHIN, H.; CHIOU, T.J.; KATAGI, H.; DEWBRE, G.R.; WEIGEL, D. and HARRISON, M.J.
Transformation of Medicago truncatula via infiltration of seedlings or flowering plants with Agrobacterium. The plant Journal, June 2000, vol. 22, no. 6, p. 531-541.

TUSCHL, T. RNA sets the standard. Nature, January 2003, vol. 421 , no. 6920 , p. $220-221$.

TWELL, D.; PARK, S.K.; HAWKINS, T.J.; SCHUBERT, D.; SCHMIDT, R.; SMERTENKO, A. and HUSSEY, P.J. MOR1/GEM1 has an essential role in the plant-specific cytokinetic phragmoplast. Nature Cell Biology, September 2002, vol. 4, no. 9, p. 711-714.

VALVEKENS, D.; VAN MONTAGU, M. and VAN LIJSE BETTENS, M. A. tumefaciencs mediated transformation of Arabidopsisthaliana root explants by using kanamycin selection. Proceedings of the National Academy of Science of the United States of America, May 1988, vol. 85, no. 10, p. 5536-5546.

VAN DER GRAAFF, E.; DULK RAS, A.D.; HOOYKAAS, P.J. and KELLER, B. Activation tagging of the Leafy petiole gene affects leaf petiole development in Arabidopsisthaliana. Development, November 2000, vol. 127, no. 22, p. 4971-4980.

VELUTHAMBI, K.; REAM, W. and GELVIN, S.B. Virulence genes, borders, and overdrive generate singlestranded T-DNA molecules from the A6 Ti plasmid of Agrobacterium tumefaciens. Journal of Bacteriology, April 1988, vol. 170, no. 4, p. 1523-1532.

VLACHONASIOS, K.E.; THOMASHOW, M.F. and TRIEZENBERG, S.J. Disruption mutations of ADA2b and GCN5 transcriptional adaptor genes dramatically affect Arabidopsis growth, development, and gene expression. Plant Cell, March 2003, vol. 15, no. 3, p. 626-638.

WALDEN, R.; FRITZE, K.; HAYASHI, H.; MIKLASHEVICHS, E.; HARLING, H. and SCHELL, J. Activation tagging: a means of isolating genes implicated as playing a role in plant growth and development. Plant Molecular Biology, December 1994, vol. 26, no. 5, p. 15211528.

WALTERS, R.G.; SHEPHARD, F.; ROGERS, J.J.; ROLFE, S.A. and HORTON, P. Identification of mutants of Arabidopsis defective in acclimation of photosynthesis to the light environment. Plant Physiology, February 2003, vol. 131, no. 2, p. 472-481.

WANG, M. and WATERHOUSE, P.M. Application of gene silencing in plants. Current Opinion in Plant Biology, April 2001, vol. 4, no.2, p.146-150.

WEBB, K.J.; SKOT, L.; NICHOLSON, M.N.; JORGENSEN, B. and MIZEN, S. Mesorhizobium loti increases root specific calcium binding protein homologue identified by promoter tagging in Lotus japonicus. 
Molecular Plant Microbe Interaction, June 2000, vol. 13, no. 6, p. 606-616.

WEI, W.; TWELL, D. and LINDSEY, K. A novel nucleic acid helicase gene identified by promoter trapping in Arabidopsis. The Plant Journal, June 1997, vol. 11, no. 6, p. 1307-1314.

WEIGEL, D.; AHN, J. H.; BLÁZQUEZ, M.A.; BOREVITZ, J.; CHRISTENSEN, S.K.; FANKHAUSER, C.; FERRÁNDIZ, C.; KARDAILSKY, I.; MALANCHARUVIL, E.J.; NEFF, M.M.; NGUYEN, J.T.; SATO, S.; WANG, Z.; XIA, Y.; DIXON, R.A.; HARRISON, M.J.; LAMB, C.J.; YANOFSKY, M.F. and CHORY, J. Activation tagging in Arabidopsis. Plant Physiology, April 2000, vol. 122, no. 4, p. 1003-1014.

WILSON, R.N. and SOMERVILLE, C.R. Phenotypic suppression of giberellin-insensitive mutant (gai) of Arabidopsis. Plant Physiology, June 1995, vol. 108, no. 2, p. $495-502$.

WINKLER, R.G.; FRANK, M.R.; GALBRAITH D.W.; FEYEREISEN, R. and FELDMANN, K.A. Systematic reverse genetics of transfer-DNA-tagged lines of Arabidopsis. Isolation of mutations in the Cytochrome P450 gene superfamily. Plant Physiology, Novemeber 1998, vol. 118, no. 3, p. 743-750.

WOO, H.R.; GOH, C.H.; PARK, J.H.; TEYSSENDIER DE LA SERVE, B.; KIM, J.H.; PARK, Y.I. and NAM, H.G. Extended leaf longevity in the ore4-1 mutant of Arabidopsis with a reduced expression of a plastid ribosomal protein gene. The Plant Journal, August 2002, vol. 31, no. 3, p. 331-340.

WU, Z.; LIANG, F.; HONG, B.; YOUNG, J.C.; SUSSMAN, M.R.; HARPER, J.F. and SZE, H. An endoplasmic reticulum-bound $\mathrm{Ca}(2+) / \mathrm{Mn}(2+)$ pump, ECA1, supports plant growth and confers tolerance to $\mathrm{Mn}(2+)$ stress. Plant Physiology, September 2002, vol. 130, no. 1, p. 128-37.

YANOFSKY, M.F.; MA, H.; BOWMAN, J.L.; DREWS, G.N.; FELDMANN, K.A. and MEYEROWITZ, E.M. The protein encoded by the Arabidopsis homeotic gene agamous resembles transcription factors. Nature, July 1990, vol. 5, no. 346 (6279), p. 35-39.

YE, G.N.; STONE, D.; PANG, S.Z.; CREELY, W.; GONZALEZ, K. and HINCHEE, M. Arabidopsis ovule is the target for Agrobacterium in planta vacuum infiltration transformation. The Plant Journal, August 1999, vol. 19, no. 3, p. 249-257.

YOUNG, J.C.; KRYSAN, P.J. and SUSSMAN, M.R. Efficient screening of Arabidopsis T-DNA insertion lines using degenerate primers. Plant Physiology, February 2001, vol. 125 , no. 2 , p. $513-518$.
YUANXIN, Y.; CHENGACAI A.; LI, L.; JIAYU, G.; GUIHONG, T. and ZHANGLIANG, C. T-linker specific ligation PCR (T-Linker PCR): an advanced PCR technique for chromosome walking or for isolation of tagged DNA ends. Nucleic Acids Research, June 2003, vol. 31, no. 12, e68.

YOSHIDA, S.; ITO, M.; CALLIS, J.; NISHIDA, I. and WATANABE, A. A delayed leaf senescence mutant is defective in arginyl-tRNA: protein arginyltransferase, a component of the N-end rule pathway in Arabidopsis. The Plant Journal, October 2002, vol. 32, no. 1, p. 129-137.

ZHU, J.; GONG, Z.; ZHANG, C.; SONG, C.P.; DAMSZ, B.; INAN, G.; KOIWA, H.; ZHU, J.K.; HASEGAWA, P.M. and BRESSAN, R.A. OSM1/SYP61: a syntaxin protein in Arabidopsis controls abscisic acid-mediated and non-abscisic acid-mediated responses to abiotic stress. Plant Cell, December 2002, vol. 14, no. 12, p. 3009-3028. 